Maurice A. Deane School of Law at Hofstra University Scholarly Commons at Hofstra Law

Hofstra Law Faculty Scholarship

$11-1997$

\title{
Tolerating Deception and Discrimination After Batson
}

Robin Charlow

Hofstra University

Follow this and additional works at: https://scholarlycommons.law.hofstra.edu/faculty_scholarship

\section{Recommended Citation}

Robin Charlow, Tolerating Deception and Discrimination After Batson, 50 Stan. L. Rev. 9 (1997)

Available at: https://scholarlycommons.law.hofstra.edu/faculty_scholarship/196

This Article is brought to you for free and open access by Scholarly Commons at Hofstra Law. It has been accepted for inclusion in Hofstra Law Faculty Scholarship by an authorized administrator of Scholarly Commons at Hofstra Law. For more information, please contact lawcls@hofstra.edu. 


\title{
ARTICLES
}

\section{Tolerating Deception and Discrimination After Batson}

\author{
Robin Charlow*
}

\begin{abstract}
Ethical issues arise when courts rule that, under Batson, attorneys have exercised unconstitutional discriminatory peremptory challenges. The strikes themselves and the pretextual explanations offered in an effort to defend the strikes may provide grounds for levying personal sanctions against the striking attorneys. This article explores the wisdom and propriety of imposing personal liability on attorneys who exercise discriminatory strikes. In the course of doing so, it examines the meaning of "pretext," the nature of "discriminatory intent" in equal protection jurisprudence, and the likely culpability or mens rea of attorneys as they engage in the prohibited conduct. It concludes that the costs of imposing such sanctions-including the risk of undeserved punishment and the adverse effect on the enforcement of Batson's antidiscrimination principlemilitate against personally punishing the attorneys in addition to remedying the unconstitutional strikes, despite the fact that some deception and discrimination will inevitably be tolerated as a result.
\end{abstract}

INTRODUCTION

I. THE RELATIONSHIP BETWEEN PRETEXT AND DISCRIMINATORY INTENT

II. PRETEXT

A. Generally ................................................................................... 20

B. In Peremptories Cases .................................................................. 21

C. In Employment Discrimination .......................................................... 23

D. The Mens Rea of Pretext in the Peremptories Context .................... 25

III. DISCRIMINATORY INTENT ....................................................................... 27

A. In Equal Protection Law Generally ................................................. 27

B. In Peremptories Cases ..................................................................... 31

* Professor of Law, Hofstra University School of Law. Thanks to Phylis Skloot Bamberger, Linda Champlin, Monroe Freedman, Mark Movsesian, and Roy Simon for their comments on drafts of this article; Nicole Zeman and especially Allen Madison for their excellent research assistance; and Hofstra Law School for its research support. 
1. Batson v. Kentucky ............................................................... 32

2. Edmonson v. Leesville Concrete Co. ...................................... 34

3. Hernandez v. New York .......................................................... 34

4. Purkett v. Elem ......................................................................... 35

C. The Mens Rea of Discriminatory Intent in the Peremptories Context ......................................................................................... 38

IV. ETHICAL IMPLICATIONS OF FINDINGS OF PRETEXT AND

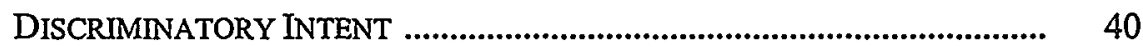

A. The Ethics of Pretexts .................................................................... 42

1. Deliberate lies ....................................................................... 42

2. Unintended pretext ................................................................. 42

3. Honest motives ...................................................................... 46

4. Mixed motives ............................................................................ 48

B. The Ethics of Discriminatory Strikes ............................................. 49

C. The Suitability of Sanctions …....................................................... 58

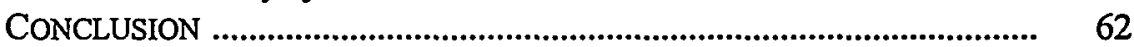

\section{INTRODUCTION}

A judge who regularly hears criminal felony cases asked my opinion about how to handle a recurring problem. She described the experience of presiding over jury selections in which one side claims that the opposing side has exercised a discriminatory peremptory challenge in violation of the Equal Protection Clause. In the now familiar procedure set forth in Batson $v$. Kentucky, ${ }^{1}$ the party making such a claim must first establish a prima facie case that the opposing party has used a peremptory challenge to exclude someone from the petit jury on account of that person's race, ${ }^{2}$ sex, ${ }^{3}$ or other protected characteristic (step one). The burden then shifts to the side exercising the peremptory "to come forward with a neutral explanation" for the strike, meaning one not based on $\operatorname{race}^{5}$ or $\operatorname{sex}^{6}$ (step two). Finally, the court must determine whether the attorney contesting the strike has established purposeful discrimination, and consequently an equal protection violation, on the part of the attorney exercising the strike (step three). ${ }^{7}$ In this last step, the court is faced with deciding whether the neutral explanation offered by the

1. 476 U.S. 79 (1986).

2. See id. at 96 .

3. J.E.B. v. Alabama ex rel. T.B., 511 U.S. 127, 144-45 (1994).

4. Batson, 476 U.S. at 97.

5. See id.

6. See J.E.B., 511 U.S. at 145.

7. See Batson, 476 U.S. at 98; see also Purkett v. Elem, 514 U.S. 765, 767 (1995) (per curiam) (summarizing the three steps comprising Batson's order of proof). 
striker is credible or instead a "pretext" for unconstitutional discrimination. ${ }^{8}$

The judge related that when she ruled that a proffered explanation was really a pretext for discrimination and that the attorney had indeed violated Batson, she had the uncomfortable feeling that she had just rendered an official ruling that the attorney was lying to the colirt and covering up unconstitutional conduct. She wondered whether this was some form of unethical behavior on the attorney's part-perhaps akin to committing or condoning perjury-and added that her implied accusation affected the remainder of the trial, producing continued discomfort whenever she interacted with the rebuked attorney. She pondered whether it was appropriate or even necessary under the judicial code of conduct to report the attorney for an ethical lapse or to impose some other sanction for misconduct.9 Her question tapped a related and growing area of concern about the need to invigorate Batson's antidiscrimination principle. ${ }^{10}$

8. See, e.g., Hernandez v. New York, 500 U.S. 352, 363 (1991) (noting that courts examine both the proffered grounds and the "totality of the relevant facts" in making a pretext determination).

9. See, e.g., Andrew G. Gordon, Note, Beyond Batson v. Kentucky: A Proposed Ethical Rule Prohibiting Racial Discrimination in Jury Selection, 62 FORDHAM L. REV. 685, 712 \& nn.279-82 (1993) (describing a case in which a United States district judge, pursuant to 28 U.S.C. $\S 1927$ and a local court rule, imposed a fine amounting to court costs on an attorney who violated Batson); $c f$., e.g., Laura Gatland, The Himmel Effect, 83 A.B.A. J., Apr. 1997, at 24, 24 (discussing the suspension of an attorney's license for failure to notify an Illinois court of a fellow lawyer's ethical breach); E. Wayne Thode, The Duty of Lawyers and Judges to Report Other Lawyers' Breaches of the Standards of the Legal Profession, 1976 UTAH L. REV. 95, 97-98, 100 (arguing that lawyers and judges, under Model Code of Professional Responsibility DR 1-103 and Code of Judicial Conduct Canon 3B(3), are obligated to-and should-report unprofessional conduct by other lawyers).

10. Concerns of this sort have been raised by critics in numerous quarters, including:

Judges. See, e.g., Minetos v. City Univ. of N.Y., 925 F. Supp. 177, 185 (S.D.N.Y. 1996) (banning peremptories altogether because they cloak racial discrimination that Batson "does not truly unmask"); Raymond J. Broderick (U.S. Dist. J.), Why the Peremptory Challenge Should Be Abolished, 65 TEMP. L. REV 369, 422 (1992) (advocating the total elimination of peremptories because Batson procedures do "not totally eliminate the discriminatory use of the peremptory challenge").

Practitioners. See, e.g., Jeffrey Toobin, Juries on Trial, THE NEW YORKER, Oct. 31, 1994, at 42,43 (suggesting the elimination of peremptories for several reasons, including the fact that, when veteran prosecutors passed on "silly little truisms" about jurors to the author and other junior prosecutors, they were really "instructing us in code to do what the Constitution forbids" under Batson).

Academics. See, e.g., Albert W. Alschuler, The Supreme Court and the Jury: Voir Dire, Peremptory Challenges, and the Review of Jury Verdicts, 56 U. CHI. L. REV. 153, 209 (1989) (proposing the elimination of peremptory challenges because Batson provides "easily evaded controls" that result in "largely ineffective remedies"); Barbara Allen Babcock, A Place in the Palladium: Women's Rights and Jury Service, 61 U. CN. L. REv. 1139, 1174-80 (1993) (suggesting that jury selection procedures be "expanded and elevated" in order to enforce Batson's antidiscrimination principle without eliminating peremptories); Sheri Lynn Johnson, Batson Ethics for Prosecutors and Trial Judges, 73 CHI.-KENT L. REV. (forthcoming 1998) (proposing questions that diligent prosecutors and judges should ask themselves before exercising and upholding peremptory challenges against members of a minority racial group); Charles J. Ogletree, Just Say No!: A Proposal to Eliminate Racially Discriminatory Uses of Peremptory Challenges, 31 AM. CRIM. L. REV. 1099, 
At first, the problem appeared deceptively simple: Does an attorney's exercise of a discriminatory peremptory challenge violate any particular ethical or other rule of practice? ${ }^{11}$ Although most states do not have ethical rules explicitly addressing discriminatory peremptories, ${ }^{12}$ some have or are considering rules barring various acts of discrimination, ${ }^{13}$ and there are univer-

1116-51 (1994) (observing that the "current application of Batson makes life more difficult for judges who reject fishy pretexts" than for litigants who offer them and exploring a wide array of remedies).

Law students. See, e.g., Tracy M.Y. Choy, Note, Branding Neutral Explanations Pretextual Under Batson v. Kentucky: An Examination of the Role of the Trial Judge in Jury Selection, 48 HASTINGS L.J. 577, 596-99 (1997) (advocating the adoption of a multifactor standard to enforce Batson and "dispel[] the fear that Batson challenges have been reduced to nothing"); Geoffrey Cockrell, Note, Batson Reform: A Lottery System of Affirmative Selection, 11 NOTRE DAME J.L. ETHICS \& PUB. POL'Y 351, 361-84 (1997) (surveying proposals to give Batson "[m]ore [t]eeth"); Patricia J. Griffin, Comment and Note, Jumping on the Ban Wagon: Minetos v. City University of New York and the Future of the Peremptory Challenge, 81 MINN. L. REV. 1237, 1267 (1997) (maintaining that the elimination of peremptory challenges altogether is "a sound solution" to the discrimination problem that persists even after Batson); Brian Wilson, Note, Batson v. Kentucky: Can the "New" Peremptory Challenge Survive the Resurrection of Strauder v. West Virginia?, 20 AKRON L. REV. 355, 364 (1986) (concluding that Batson "lacks the necessary 'teeth' required to ensure that black jurors are not excluded on the basis of race").

Those with multiple and other roles. See, e.g., Theodore McMillian (professor and U.S. Cir. J.) \& Christopher J. Petrini (judicial clerk), Batson v. Kentucky: A Promise Unfulfilled, 58 UMKC L. REV. 361, 374 (1990) (calling for the elimination of peremptories because Batson "does not go far enough" and is "ineffective $]$ in combating racial discrimination").

11. See, e.g., Gordon, supra note 9 , at $715 \&$ \& .302 (arguing that, although a discriminatory peremptory challenge does not explicitly violate any of the A.B.A. Model Rules of Professional Conduct, it "flies in the face of the tenets enunciated by the Model Rules"). It is possible that a discriminatory peremptory strike violates Rule 3.4(c) of the A.B.A. Model Rules (modeled after former A.B.A. Model Code of Professional Responsibility DR 7-106(A)), which instructs lawyers not to "knowingly disobey an obligation under the rules of a tribunal." MODEL RULES OF PROFESSIONAL CONDUCT Rule 3.4(c) (1992). However, it is not clear whether the implied obligation not to act unconstitutionally created by Batson and its progeny would be considered "an obligation under the rules of a tribunal," or whether Rule 3.4(c) refers only to more formal rules or orders of a court explicitly stated orally or in writing.

12. The only rule to date that expressly bars discriminatory peremptory challenges is a District of Columbia rule addressing prosecutors in criminal cases. See D.C. RULES OF PROFESSIONAL CONDUCT Rule 3.8(h) ("The prosecutor in a criminal case shall not ... [p]eremptorily strike jurors on grounds of race, religion, national or ethnic background, or sex.").

13. Three states have rules that explicitly bar discrimination against jurors, but that do not expressly mention peremptory challenges. For example, Florida's rules establish that

[a] lawyer shall not ... engage in conduct ... that is prejudicial to the administration of justice, including to knowingly, or through callous indifference, ... discriminate against . . . jurors ... on any basis, including, but not limited to, on account of race, ethnicity, gender, religion, national origin, disability, marital status, sexual orientation, age, socioeconomic status, employment, or physical characteristic.

FLA. RULES OF PROFESSIONAL CONDUCT Rule 4-8.4(d); see also Ill. Rules of PROFESSIONAL CONDUCT Rule 8.4(a)(5) ("A lawyer shall not ... engage in adverse discriminatory treatment of ... jurors . . . based on race, sex, religion, or national origin."); R.I. RULES OF PROFESSIONAL CONDUCT Rule 8.4(d) (making it "professional misconduct for a lawyer to . . . engage in conduct that is prejudicial to the administration of justice, including . . . discriminatory treatment of . . . jurors ... based on race, nationality, or sex"). 


\section{sally applicable rules banning the making of false statements or misrepre-} sentations to a court. ${ }^{14}$ Surely a "pretext" offered to explain or excuse un-

Several other states prohibit discrimination more generally in the practice of law. See IowA CODE OF PROFESSIONAL RESPONSIBILITY DR 1-102(A)(7) (barring lawyers from engaging in "sexual harassment or other unlawful discrimination on the basis of sex, race, national origin, or ethnicity"); MINN. RULES OF PROFESSIONAL CONDUCT Rule 8.4(g)-(h) ("It is professional misconduct for a lawyer to . . . harass a person . . . or commit a discriminatory act . . . ."); N.J. RULES OF PROFESSIONAL CONDUCT Rule 8.4(g) (barring discrimination "in a professional capacity"); N.Y. CODE OF PROFESSIONAL RESPONSIBILITY DR 1-102(a)(6) (specifically barring employment-related discrimination); WASH. RULES OF PROFESSIONAL CONDUCT Rule $8.4(\mathrm{~g})$ (barring illegal acts of discrimination committed in connection with professional activities); see also RULES AND REGULATIONS FOR THE ORGANIZATION AND GOVERNMENT OF THE STATE BAR OF GA., General Aspirational Ideals (c) (exhorting lawyers to "aspire ... [t] avoid all forms of wrongful discrimination in all of [their] activities").

Some states censure discrimination in particular aspects of legal practice. See CAL. RULES OF PROFESSIONAL CONDUCT Rule 2-400(B)(1)-(2) (specifically prohibiting discrimination by a law practice in employment and client representation); MASS. CODE OF PROFESSIONAL RESPONSIBILITY DR 7-106(C)(8) ("In appearing . . . before a tribunal, a lawyer shall not ... [e]ngage in conduct manifesting bias or prejudice ...."); MO. RULES OF PROFESSIONAL CONDUCT Rule $8.4(\mathrm{~g})$ (making it professional misconduct for a lawyer to "manifest . . . bias or prejudice" in representing a client, with an exception for "legitimate advocacy"); N.M. RULES OF PROFESSIONAL CONDUCT Rule 16-300 (creating a rule similar to that of Massachusetts, but governing only "judicial or quasi-judicial proceedings"); TEX. DISCIPLINARY RULES OF PROFESSIONAL CONDUCT Rule 5.08(a)-(b) (prohibiting a lawyer from wilfully manifesting bias or prejudice in adjudicatory proceedings, but explicitly exempting "the process of jury selection"); VT. CODE OF PROFESSIONAL RESPONSIBILITY DR 1-102(A)(6) (barring discrimination in the employment context only).

Still other states caution broadly against discriminatory activities. See Colo. RULES OF PROFESSIONAL CONDUCT Rule 1.2(f) (providing that, in representing a client, a lawyer shall not exhibit, intentionally appeal to, or engender bias against a person "on account of that persons [sic] race, gender, religion, national origin, disability, age, sexual orientation, or socioeconomic status"); IDAHO RULES OF PROFESSIONAL CONDUCT Rule 4.4(a) (barring attorneys from appealing to or engendering bias); MICH. RULES OF PROFESSIONAL CONDUCT Rule 6.5(a) (directing lawyers to "avoid treating [any person involved in the legal process] discourteously or disrespectfully because of the person's race, gender, or other protected personal characteristic").

For discussions of the most recent considerations of various antidiscrimination proposals by several states and the A.B.A., see STEPHEN GILLERS \& ROY D. SIMON, JR., REGULATION OF LAWYERS: STATUTES AND STANDARDS 390-405 (1997) (Rule 8.4), and Conference Looks at Need for Special Disciplinary Standaras for Criminal Lawyers, Proposed Anti-bias Rule, 61 Crim. L. Rep. (BNA) 1248, 1250 (June 11, 1997). See also ABA Panel Proposes New Language in Model Rules Condemning Bias by Lawyers, 66 U.S. Law Week (BNA) 2342, 2342-43 (Dec. 9, 1997) (reporting on a proposed antibias amendment to the Model Rules of Professional Conduct to be considered at the A.B.A.'s February 1998 meeting).

14. At one time, all 50 states and the District of Columbia had adopted some form of the A.B.A. Model Code of Professional Responsibility, usually with only modest changes (except in Califomia). See GILlers \& Simon, supra note 13, at xxii. Disciplinary Rules 7-102(A)(5) and 1$102(\mathrm{~A})(4)$ of the Model Code admonished attorneys not to make false statements of law or fact to a court or engage in conduct involving dishonesty or misrepresentation. See MODEL CODE OF PROFESSIONAL RESPONSIBILITY DR 7-102(A)(5) (1980) "In his representation of a client, a lawyer shall not ... [k]nowingly make a false statement of law or fact."); DR 1-102(A)(4) (1980) (prohibiting attorneys from engaging in "conduct involving dishonesty, fraud, deceit, or misrepresentation"). The A.B.A. later replaced the Model Code with the Model Rules of Professional Conduct, which, by 1995, had been adopted, in large measure, by 38 states and the District of Columbia and, in part, by some other states. See GILLER \& SMON, supra note 13, at xxii. Model Rule 3.3(a)(1) 
constitutional conduct is a misrepresentation, and a material one at that.

But the issue facing my friend on the bench was not nearly that straightforward. What does it really mean to assert a "pretext" in this context? Does it mean to lie? Must the lie be conscious and intentional? And more confounding, what does it mean to have engaged in unconstitutional discrimination in such a situation? Is it tantamount to having done something morally or socially repugnant? Deliberately so? Is the conduct sufficient to warrant professional censure? Finally, could the peremptory challenge-and many other aspects of our justice system ${ }^{15}$ - survive the prospect of sanctions against individual attorneys in such circumstances?

In the end, I realized that my judicial friend's seemingly direct problem was rife with implications for some of the most perplexing issues in constitutional law, criminal law, and legal ethics. ${ }^{16}$ One cannot fully address her question without at least some understanding of the meaning of the terms

is substantially similar to Disciplinary Rule 7-102(A)(5), and Model Rule 8.4(c) is substantially similar to Disciplinary Rule 1-102(A)(4). See MODEL RULES OF PROFESSIONAL CONDUCT Rule 3.3(a)(1) ("A lawyer shall not knowingly ... make a false statement of material fact or law to a tribunal."); $i d$. Rule 8.4(c) ("It is professional misconduct for a lawyer to ... engage in conduct involving dishonesty, fraud, deceit or misrepresentation ...."). As a result, either the older Model Code's Disciplinary Rules barring false statements and misrepresentation or the newer Model Rules to the same effect currently apply in 49 states and the District of Columbia. The remaining state, California, has its own rules admonishing against similar conduct. See CAL. RULES OF PROFESSIONAL CONDUCT Rule 5-200(B) (providing that an attorney "[s] hall not seek to mislead the judge, judicial officer, or jury by an artifice or false statement of fact or law"); CAL. BUS. \& PROF. CODE $\S 6106$ (West 1990) (making the commission of any act of dishonesty "a cause for disbarment or suspension"). Thus, rules prohibiting attorneys from making false statements or misrepresentations to a court are essentially universal throughout the country.

15. The imposition of personal sanctions in these circumstances might stimulate calls for personal sanctions in numerous other circumstances in which attorneys act questionably, but in a professional, advocative capacity. For example, one might consider personal sanctions against those who use controversial closing arguments. See, e.g., Raymond R. Coffey, Veieran Lawyer Says Trial Makes Case for Ban on TV, CHI. SUN-TMMES, Oct. 3, 1995, at 4 (describing Johnnie Cochran's closing argument in the murder trial of O.J. Simpson as controversial for "urging the mostly black jury to acquit Simpson as a blow against racism"); Henry Weinstein, Lawyer's Family Tragedy Inspires Hitler Reference, L.A. TimES, Sept. 30, 1995, at 1 (noting condemnation of Cochran's closing argument in the murder trial of O.J. Simpson, which controversially described a prosecution witness as a verbally racist detective comparable to Hitler). Similar sanctions might be advisable for prosecutors (and even judges?) who allow witnesses to present dubious testimony. See, e.g., Mark Curriden, The Lies Have It, 81 A.B.A. J., May 1995, at 68, 71-72 (1995) (detailing evidence of widespread, unpunished perjury by witnesses and reports of attomeys condoning such perjury). Indeed, lawyers could conceivably incur personal sanctions for any act ruled unconstitutional.

16. This experience counters the currently popular lament that esoteric academia is disconnected from the everyday work of the bar. See, e.g., Robert MacCrate, Peter W. Martin, Peter A. Winograd \& Michael Norwood, Legal Education and Professional Development-An Educational Continuum, 1992 A.B.A. SEC. LEgAL EDUC. AND ADMISSIONS TO THE BAR 5 ("Practitioners tend to view much academic scholarship as increasingly irrelevant to their day-to-day concerns ...."); Jason A. Lief, Political Correctness Deadens Scholarship, NAT'L L.J., Aug. 21, 1995, at A19, A19 ("The legal scholar's duty to engage in a true dialogue about law has been replaced by a disillusioned meandering into the 'philosophical' abyss."). 
"pretext" and "discriminatory intent," the latter a perennial favorite of commentators and an often disputed issue in constitutional jurisprudence. Moreover, after determining what it means to exercise a peremptory with "discriminatory intent" or to offer a "pretext" for doing so, one must decide whether such conduct is reprehensible. Evaluating blameworthiness requires an assessment of the kind of scienter or mental state that accompanies such conduct. This means examining mens rea, one of the most confusing aspects of criminal law. Finally, after identifying the meaning of these acts and the culpability attached to them, one must decide the ethical issues: whether such acts are so abhorrent that they warrant professional sanctions no matter what the attorney's intent; whether they should be punished in proportion to the accompanying intent; or whether, in some circumstances, they should not be punished at all, even if they involve a deliberate intent to deceive the court (in the case of a pretext) or to exclude a potential juror on the basis of that person's race or sex (in the case of a discriminatory strike). Although I discuss these issues in the context of a Batson violation, comparable concerns are raised by numerous other instances of similarly questionable behavior and unconstitutional acts.

Part I of this article outlines how the concepts of pretext and discriminatory intent relate to one another in the Batson context. Part II undertakes to flesh out some of the possible meanings of "pretext," and Part III examines "discriminatory intent," as the terms are used in this setting. After each term is defined, Parts $I I$ and III explore the scienter or mental states that might accompany the offer of a pretext or a strike with discriminatory intent.

Part IV of the article discusses which, if any, permutations of conduct and mental states call for censure and whether it is possible and profitable to identify which combination is present in an actual case and impose a suitable sanction. The article provides neither a detailed examination of the ethical rules governing attorney conduct nor their underlying premises and goals. ${ }^{17}$ Rather, it considers the propriety of imposing any personal sanction against an attorney who violates Batson, not exclusively the sanctions involved in professional disciplinary proceedings. ${ }^{18}$

I argue that not all Batson violations warrant the imposition of personal sanctions. It will be too difficult in most circumstances-with the possible exception of particularly obvious and egregious instances of intentional conduct-to distinguish between those cases that warrant sanctions and those

17. For a discussion of the purpose of the ethical rules and an argument advocating a new rule to bar discrimination in jury selection, see Gordon, supra note 9, at 710-18.

18. See, e.g., Ogletree, supra note 10 , at 1122 (listing disciplinary actions that might be invoked against prosecutors who violate Batson, including contempt citation, censure or reprimand, removal from court, temporary suspension, referral to disciplinary bodies, and criticism in published judicial opinions). 
that do not. Moreover, I argue that courts may be discouraged from finding Batson violations altogether because of the prospect of personal sanctions attaching to the attorneys involved. I also maintain that if Batson's antidiscrimination principle were vigorously enforced, there might be an increase in the findings of equal protection violations, but concomitantly less justification for the imposition of personal sanctions on the errant attorneys. Perhaps most controversially, I note that the uncomfortable fit between the central aim of Batson and the purposes of peremptory challenges indicates that at least some Batson violations are not ill-intentioned and may not warrant professional censure. For these and other reasons, the article concludes that personal sanctions-beyond the remedies imposed for the equal protection violation itself-should seldom be levied, even though some cases of deliberate deception and discrimination would thereby likely go unpunished.

\section{The RELATIONSHIP BETWEEN PRETEXT AND DISCRIMINATORY INTENT}

Before attempting to define pretext and discriminatory intent, we need a better understanding of the relationship between the two concepts in a Batson setting. As mentioned above, in the second step of a Batson inquiry, the striking attorney presents his reason (or reasons) for excusing a prospective juror; then, in the third step, the court determines whether the attorney engaged in unconstitutional discrimination by striking the potential juror because of that person's race or sex. ${ }^{19}$ The court frequently makes the stepthree determination by considering the reason given in step two. If the court finds that the explanation offered was a pretext, it usually finds that the real reason was an intent to discriminate on the basis of race or sex-the requisite discriminatory purpose or intent to establish an equal protection violation. ${ }^{20}$ In other words, a ruling that the step-two reason was a pretext usually means that it was a pretext for what was actually unconstitutional discrimination. Consequently, a finding of pretext may, and often does, serve as very strong evidence of unconstitutional discriminatory intent. ${ }^{21}$

19. See text accompanying notes 4-7 supra.

20. See David A. Sutphen, Note, True Lies: The Role of Pretext Evidence Under Batson v. Kentucky in the Wake of St. Mary's Honor Center v. Hicks, 94 MiCH. L. REV. 488, 501 (1995) (noting that "proof of pretext under Batson is the legal equivalent to proof of intentional discrimination" and that judges place so much importance on pretext evidence that many Batson motions tum on whether the judge finds the proffered reasons pretextual).

21. Cf. Hernandez v. New York, 500 U.S. 352, 367 (1991). The Court noted:

[I]f an appeliate court accepts a trial court's finding that a prosecutor's race-neutral explanation for his peremptory challenges should be believed, we fail to see how the appellate court nevertheless could find discrimination. The credibility of the prosecutor's explanation goes to the heart of the equal protection analysis, and once that has been settled, there seems nothing left to review. 
Technically, however, a finding of pretext does not necessarily require a subsequent finding of discriminatory intent. ${ }^{22}$ An attorney might offer a pretextual explanation in order to hide motives that are not invidiously discriminatory. For example, suppose an attorney defending a man accused of raping a woman strikes a venirewoman because she looks and acts uncannily like his second-grade teacher, with whom he had a difficult time. When this strike is later challenged, he does not want to reveal his embarrassing explanation to the court for fear of appearing unprofessional. Instead, he explains that he struck the woman because she seemed disdainful and appeared to react to him disapprovingly and that he was afraid that this perceived attitude would redound to his client's detriment. On hearing this explanation, the judge could discredit it for, among other things, absence of evidentiary support. At the same time, the judge might quite correctly find that the real reason for the strike was not a desire or plan to eliminate women from the venire on account of their sex..$^{23}$ Perhaps the attorney had, by that point, struck

22. But cf. id. (maintaining, conversely, that the court's crediting a striker's race-neutral explanation for a challenged peremptory effectively precludes the court from finding discriminatory intent).

Even in a case in which the court finds that a pretext is used to mask invidious discriminatory intent, under traditional equal protection doctrine, the court could still find no constitutional violation. This would occur if the discriminatory strike could be justified under the applicable standard of review. For example, if the strike were found racially discriminatory, it would have to satisfy the strict scrutiny standard of review in order to be constitutional. See J.E.B. v. Alabama ex rel. T.B., 511 U.S. 127, 154 (1994) (Rehnquist, J., dissenting). That is, the strike must have been exercised on racial grounds for a compelling reason, and it must have been a remedy narrowly tailored to meet that compelling goal. See Shaw v. Hunt, 116 S. Ct. 1894, 1902 (1996). If the court considered the strike to be discriminatory on the basis of sex, the strike would have to satisfy the less searching standard of intermediate scrutiny. See J.E.B., 511 U.S. at 136, 154. That is, a sex-based strike would have to substantially further an important or "exceedingly persuasive justification." Id. at $136,141 \mathrm{n} .12,160$.

However, the state's interest in a discriminatory peremptory challenge is unlikely ever to meet the applicable standard. See id. at 160-61 (Scalia, J., dissenting). J.E.B. v. Alabama, the only case in which the Supreme Court appears to have acknowledged that it should examine the state's countervailing interest against the equal protection right at issue, involved measuring a sex-based exclusion against the purported state interest in "achieving a fair and impartial trial." Id. at 136-37. Although Chief Justice Rehnquist found that the state's interest outweighed the asserted equal protection right, see id. at 156, the majority did not agree, see id. at 136-38; see also Batson v. Kentucky, 476 U.S. 79, 124-26 (1986) (Burger, C.J., dissenting) (criticizing the majority for not following the usual equal protection analysis, including consideration of the "substantial, if not compelling," state interest in preserving the ancient and venerable peremptory challenge as a means to insure against bias). Thus, the state's interest in protecting a party's ability to seat a jury more well-disposed (or less ill-disposed) to his case does not appear sufficiently compelling, as a matter of law, to overcome race or sex discrimination in the exercise of peremptories. Although a generalized state interest in protecting all parties in this way does not rise to the necessary level, the state's interest in ensuring faimess and impartiality (or even the appearance thereof) for a criminal defendant presents a more compelling case. But see Bridges v. State, 695 A.2d 609, 617 (Md. Ct. Spec. App. 1996) (reasoning that an attomey who exercised a peremptory based on a "suspect' classification" could never satisfy the heightened scrutiny requirement unless he also would have been able to exercise a challenge for cause).

23. In the jury selection "folklore" described by Michael Hoenig in Peremptory Challenges 
several men from the jury, but no other women. ${ }^{24}$ In such a case, the judge might find pretext but not discriminatory intent.

On the flip side, even if the explanation proffered in step two is not found to be a pretext, there may be other evidence that the attorney acted with discriminatory intent in exercising the strike. ${ }^{25}$ In such a case, there could be an equal protection violation, based on discriminatory intent, even without a finding of pretext. For example, the attorney may have acted with mixed motives. One of his reasons for the strike might have been something other than race or sex, and this could be offered in step two as a nondiscriminatory reason. This explanation would not be a pretext because it was a genuine motivation for the strike. However, a second reason for striking the potential juror might have been the person's race or sex. Although this latter

Revisited, N.Y. L.J., Oct. 14, 1992, at 3, one finds the perceived wisdom that female jurors are less sympathetic than male jurors to defendants in male-on-female rape cases. See Susan W. Brenner, Voir Dire and Jury Selection, in 1A CRIMINAL DEFENSE TECHNIQUES $\$ 21.04$, at 21-75 (Steven W. Allen, Irene H. Rosen, Douglas L. Winston \& Ellen D. Smolinsky eds., 1991) ("[T] he defendant in a rape case would not be likely to fare well if he were tried by a jury of young women."); Anne Rankin Mahoney, Sexism in Voir Dire: The Use of Sex Stereotypes in Jury Selection, in WOMEN IN THE COURTS 114, 121, 125-27 (Winifred L. Hepperle \& Laura Crites eds., 1978) (citing the perceived wisdom, but questioning its accuracy); see also J.E.B., 511 U.S. at $138 \mathrm{n} .9$ (citing one study, reported in ReID Hastie, StEven D. PENROD \& NANCY PENNINGTON, INSIDE THE JURY 140 (1983), concluding that female jurors appear somewhat more conviction prone than male jurors in rape cases); id. at 148-49 (O'Connor, J., concurring) (describing Inside the Jury as having surveyed "a plethora of studies" that came to this same conclusion).

24. The pattern of strikes exercised by an attorney may be used as evidence of discriminatory intent. See Batson, 476 U.S. at 97; People v. Jenkins, 554 N.E.2d 47, 50 (N.Y. 1990) (finding a pattern establishing a prima facie case of discrimination where, in seven of ten peremptory challenges, the prosecutor struck seven of the ten blacks who were on the venire and who comprised "a heterogeneous group of both sexes with different occupations and social backgrounds"); see also Samo v. Colfax, No. A-2538-94TI, slip op. at 5-6 (N.J. Super. Ct. App. Div. Aug. 19, 1996) (finding "a pattern of impermissible exclusion" in the defendants' exercise of peremptory challenges against all four minority group members in the juror pool, even though the trial judge said that each of the first three challenges "could have had some valid reason"). But see People v. Childress, 614 N.E.2d 709, 711 (N.Y. 1993) (rejecting a claim that striking two of the three African American venirepersons established a pattern of purposeful exclusion); Kenneth J. Melilli, Batson in Practice: What We Have Learned About Batson and Peremptory Challenges, 71 NOTRE DAME L. REv. 447, 470-78 (1996) (analyzing and critiquing the mathematical models courts have used to identify whether there exists a pattern of discriminatory strikes).

Presumably, as in the text's hypothetical, the converse could be true as well: A particular pattern of strikes might also be evidence of an absence of discriminatory intent. See, e.g., Carroll v. State, No. CR-95-1248, 1996 WL 549097, at *5-*6 (Ala. Ct. App. Sept. 27, 1996) (finding no Batson violation where three black prospective jurors, but also one white prospective juror, were struck for saying they believed that police misconduct had occurred in the O.J. Simpson case).

25. One court has indicated that the opposing attomey may attack the striking attomey's articulated reasons not only as pretextual, but alternatively, as insufficient. See State v. Robinson, 676 A.2d 384, 387 (Conn. 1996) (citing State v. Hinton, 630 A.2d 593, 604 (Conn. 1993)). This court's reasoning suggests that pretext is not the only basis for establishing purposeful discrimination and an equal protection violation. But see Sutphen, supra note 20, at 510 (noting that, "in the vast majority of cases, the most that the defense can prove is pretext" because "aside from pretext there is little evidence available to the defendant" to establish discriminatory intent). 
explanation obviously would not be proffered, in an unusual case there could conceivably be other evidence of the attorney's invidious intent. Hence, this mixed motives example could involve discriminatory intent without a proffered pretext.

To illustrate this point, again consider the rape case example from the previous paragraph. Suppose the attorney struck the venirewoman both because she reminded him of his second-grade teacher and because he credited the commonly held belief that female jurors are less sympathetic than male jurors to male defendants accused of rape. ${ }^{26}$ Suppose he offered the first reason, which was truthful, and it was accepted as such by the court. If he had read the case law, he would know not to offer his second reason. But suppose the court surmised that the attorney harbored a discriminatory intent to strike women, perhaps because, by that time, the attorney had struck several other women for weakly plausible reasons, but never any men to whom similar factors applied. ${ }^{27}$ Taking this pattern into account, the court could find that, despite the individually acceptable explanations, the totality of the circumstances pointed to discriminatory intent. ${ }^{28}$ In such a case, the discriminatory purpose for the strike-the desire to eliminate female jurorswould render the strike unconstitutional, ${ }^{29}$ despite the fact that the proffered

26. See note 23 supra.

27. See, e.g., Turner v. Marshall, 121 F.3d 1248, 1254 (9th Cir. 1997) (noting that some justifications for peremptory challenges "may be vulnerable to a comparative attack"); United States v. Chinchilla, 874 F.2d 695, 698-99 (9th Cir. 1989) (holding that because a prosecutor struck the only Hispanic prospective juror, purportedly owing to his residence, but did not strike a non-Hispanic prospective juror who lived in the same neighborhood, "[s]uch disparate treatment is strongly suggestive of bias" violative of Batson (quoting People v. Hall, 672 P.2d 854, 858 (Cal. 1983))); Childress, 614 N.E.2d at 711 (stating that a prima facie case of discrimination "may be established by a showing that members of the cognizable group were excluded while others with the same relevant characteristics were not"); see also Melilli, supra note 24, at 479-80 (1996) (surveying nearly every reported decision applying Batson between April 30, 1986, and December 31, 1993, and indicating that the disparate treatment of potential jurors belonging to different groups "is by far the most prevalent rationale for rejecting proffered neutral explanations" in Batson challenges).

28. The Connecticut Supreme Court recently recognized that the evidentiary basis for making a Batson claim relating to individual venirepersons may not arise until after a series of peremptory strikes, each of which might have individually appeared proper. See Robinson, 676 A.2d at 389-90. At this point, the attomey's treatment of all the persons on the venire is available for comparison. See id. at 389-91.

29. That is, the discriminatory purpose would render the strike unconstitutional unless the same decision would have been reached without regard to the impermissible purpose. See Hunter v. Underwood, 471 U.S. 222, 228 (1985) ("Once racial discrimination is shown to have been a "substantial' or 'motivating' factor behind [government action], the burden shifts to the [government] to demonstrate that the [action] would have been [taken] without this factor."); Howard v. Senkowski, 986 F.2d 24, 30 (2d Cir. 1993) (ruling that "dual motivation analysis" determines whether a prosecutor violates Batson when he considers both race-based and race-neutral factors in exercising a peremptory strike and leaving to the prosecutor the defense that such a strike would have been exercised for the race-neutral reasons in the absence of improper racial motives); see also Wallace v. Morrison, 87 F.3d 1271, 1274-75 (11th Cir. 1996), cert. denied, 117 S. Ct. 616 (1996); United States v. Darden, 70 F.3d 1507, 1531 (8th Cir. 1995), cert. denied, 116 S. Ct. 1449 (1996); Jones v. 
explanation was not a pretext and was found credible by the court.

Neither of the previous hypotheticals should be understood to represent commonly occurring situations. In the vast majority of cases, pretext will be the only evidence of discriminatory intent, and a finding of pretext will demonstrate such intent..$^{30}$ In fact, these two determinations are often integrally intertwined. It is likely that courts often decide simultaneously that the proffered explanation is a pretext and that the real reason for the strike was forbidden discrimination. In such commonly occurring cases, the court technically makes two separate determinations, but in reality it makes only one.

Nevertheless, the court eventually articulates separate conclusions as to pretext and discriminatory intent, and for the reasons mentioned above, it may find one but not the other, however rarely. The attorney has performed two acts, each of which could give rise to different ethical ramifications. As a result, either offering a pretextual explanation or exercising a discriminatory challenge could independently be the basis for a possible ethical problem. For that reason, this article will examine the dynamics of each separately.

\section{PRETEXT}

\section{A. Generally}

Pretext is defined in standard dictionary terms as "a purpose or motive alleged or an appearance assumed in order to cloak the real intention or state of affairs," "31 "a false reason or motive put forth to hide the real one," or an "excuse," "cover-up," or "front." 32 The dictionary definition of "pretext" implies a conscious and deliberate act of deception-a scienter of purpose to deceive. If a false purpose or motive is alleged "in order to" hide one's true purpose, then presumably the decision to mask the true purpose is a conscious and deliberate act.

Plaster, 57 F.3d 417, 421 (4th Cir. 1995). Also, a strike exercised for a discriminatory purpose would not violate the Constitution if the strike could be justified under the applicable level of scrutiny for such discriminatory conduct. See note 22 supra.

30. See Hernandez v. New York, 500 U.S. 352, 365 (1991) ("In the typical peremptory challenge inquiry [into discriminatory intent], the decisive question will be whether counsel's raceneutral explanation for a peremptory challenge should be believed."); Sutphen, supra note 20, at 508 ("Batson recognizes that pretextual justifications for peremptory strikes almost certainly reveal discriminatory animus."); $i d$. at 510 ("[I]n the vast majority of cases, the most that the defense can prove is pretext."). 1987).

31. Webster's Ninth New Collegiate DictionaRY 932 (Frederick C. Mish ed., 9th ed.

32. WEBSTER'S NEW WORLD DiCTIONARY 1067 (Victoria Nuefeldt ed., 3d College ed. 1988); see also THE CONCISE OXFORD DICTIONARY OF CURRENT ENGLISH 1083 (Della Thompson ed., 9th ed. 1995) (defining pretext as "an ostensible or alleged reason or intention" or "an excuse offered"). 
The Court uses the term "pretext" to refer to a reason given for exercising a peremptory challenge that the trial court finds to be a cloak for an attorney's true motive in striking a prospective juror. Applying the dictionary definition to the Batson context, presumably the attorney offering the pretext is doing so with a purpose to deceive. But does the Court use the term "pretext" in exactly this way in Batson cases?

\section{B. In Peremptories Cases}

Although the Supreme Court has devoted surprisingly little discussion to the issue of pretext in peremptories opinions, the available evidence reveals that the Court does not necessarily employ the concept of pretext in accordance with its dictionary definition and implied scienter. The majority opinion in Batson, which first enunciated the pretext consideration, does not especially illuminate the point or even use the term "pretext." However, Justice Marshall had something to say about the topic in his concurrence.

Justice Marshall's opinion first illustrates how prosecutors can easily fabricate facially neutral reasons for striking potential jurors, reasons which trial courts are ill-equipped to second-guess. ${ }^{33}$ It then asserts that "outright prevarication" is not the only danger, but that attorneys may even engage in self-deception in order to convince themselves that their motives are legal. ${ }^{34}$ According to Justice Marshall, this self-deception may result from the attorney's conscious or unconscious racism, and similarly, the judge may accept the resulting pretextual explanation for a strike due to his own conscious or unconscious racism..$^{35}$ Justice Marshall's depiction of how pretext operates in actual cases accepts a notion of the term that goes beyond the kind of overt lying that the dictionary describes.

To be sure, pretext includes instances of "outright prevarication" from which one might surmise that the attorney deliberately attempted to mislead the court in order to cloak his true intentions. Another of the peremptories cases, Purkett v. Elem, ${ }^{36}$ discusses this kind of pretext. Justice Stevens' dissent in Elem cites Hernandez v. New York, ${ }^{37}$ an earlier peremptories case, for the proposition that an explanation unrelated to the particular circumstances of the trial may be found to be a pretext for purposeful discrimination. ${ }^{38}$ The

33. See Batson v. Kentucky, 476 U.S. 79, 105-06 (1986) (Marshall, J., concurring).

34. Id. at 106 (citing King v. County of Nassau, 581 F. Supp. 493, 501-02 (E.D.N.Y. 1984)).

35. See id. In describing the role of unconscious racism, Justice Marshall picks up on dissenting Justice Rehnquist's description of peremptories as based on "seat-of-the-pants instincts," which Marshall says may often be nothing more than racial prejudice. He then argues that even parties with the "best of conscious intentions" would have to "confront and overcome their own racism on all levels," something he doubts that all can do. Id.

36. 514 U.S. 765 (1995) (per curiam).

37. 500 U.S. 352 (1991).

38. See Elem, 514 U.S. at 774 n.7 (Stevens, J., dissenting). 
per curiam opinion in Elem adds that "implausible or fantastic justifications" for strikes are likewise fertile grounds for findings of pretext. ${ }^{39}$ Explanations that are unrelated to the trial or simply fantastic may themselves give the court reason to doubt the attorney's honesty in making the proffers. ${ }^{40}$

But Justice Marshall also understood that there may be instances in which an attorney offering a pretext is unaware of his own unconstitutional, racial motivation. In these cases, the attorney might "lie to himself," concluding, for example, that a black prospective juror is "sullen" or "distan" when he would not have characterized an otherwise identical white prospective juror in the same way. ${ }^{41}$

Presumably, courts will be able, on occasion, to smoke out these instances of self-deception or unconscious racism and label them pretext. For example, a court might find pretext in a case of unconscious racism where the explanation offered for the strike involves a factor that has a grossly disproportionate impact on a specially protected class. In Hernandez, the prosecutor stated that he excused two potential jurors who apparently spoke Spanish because he believed they might not accept the official translation of the testimony. 42 This basis for exclusion had a disproportionate effect on Latinos, and the defense argued that it was unconstitutionally discriminatory in part for that reason. ${ }^{43}$ Justice O'Connor, in a concurring opinion, concluded that disparate impact could constitute evidence of intentional discrimination and that such an impact could cause a trial judge to disbelieve the asserted justification and find it to be a pretext. ${ }^{44}$ In a case of disparate impact like Hernandez, the striking attorney might act with an unconscious discriminatory intent - unaware that he really meant to exclude Latinos-yet following Justice O'Connor's reasoning, the trial court could nonetheless find that the attorney's explanation was a pretext. ${ }^{45}$

39. Id. at 768 .

40. These are likely to be instances of intentional prevarication, but not necessarily. See text accompanying notes $41-45$ infra.

41. Batson v. Kentucky, 476 U.S. 79, 106 (1986) (Marshall, J., concurring).

42. See Hernandez, 500 U.S. at 356-57.

43. See id. at 360.

44. See id. at 375 (O'Connor, J., concurring).

45. This was not what the trial court found in Hernandez, however, and it is not clear that Justice O'Connor meant for her statement about disparate impact as circumstantial evidence of intent to apply to instances of unconscious racism. Cf. J.E.B. v. Alabama ex rel. T.B., 511 U.S. 127, 143 \& n.16 (1994) (reiterating, in a majority opinion joined by Justice O'Connor, that strikes based on characteristics disproportionately associated with a protected class could be constitutional absent a showing of pretext).

Sometimes it is particularly difficult to discern whether a decision is based on race. Consider an example that arose in the recent rash of arsons committed against predominantly black churches in the rural South. In one incident in which a white, 17-year-old volunteer firefighter confessed to the crime, the local district attomey said that race did not appear to be a factor in the incident. But North Carolina's Attorney General, Michael Easley, would not concur, noting that the youth who 
No ethical problem would arise in these instances of self-deception unless courts somehow unmasked the unconscious motives and made findings of pretext. However, if courts occasionally make such findings even in cases in which attorneys have "lied to themselves," then findings of pretext may target not only deliberate lying, but also unintentional falsehood. The question then is how to treat attorneys who offer pretextual explanations for discriminatory strikes, but who do so without a deliberate purpose to deceive.

Furthermore, some cases in which courts use circumstantial evidence to conclude that an attorney is offering a pretext may involve neither intentional deception nor unconscious racism. Recall that the Court in Hernandez concluded that explanations unrelated to the particular facts of the case may lead a court to find pretext. ${ }^{46}$ When an attorney offers an explanation unrelated to the case, there is reason to think he may be consciously lying in order to cover up unconstitutional discrimination. After all, it is not often that reasons unrelated to the case cause a lawyer to strike a prospective juror. But the attorney who offers such an extraneous reason is not necessarily lying. ${ }^{47}$ For example, in an earlier hypothetical, an attorney struck a venirewoman because she reminded him of an especially disfavored former schoolteacher. ${ }^{48}$ Although the attorney hid the fact that his strike was based on unpleasant childhood memories, the court might have suspected a pretext even if he had revealed the true basis of his strike. However silly such a strike might seem, and however rarely it occurs, some such cases undoubtedly exist. If we are to determine the personal culpability of attorneys found to have offered pretextual explanations for strikes, even these innocent instances must be considered. In such cases, it seems fairly clear that the attorney allegedly offering the pretext did not deliberately lie or even make an unconscious misrepresentation to the court.

\section{In Employment Discrimination}

Because the Court has rarely elaborated on pretext in the peremptories cases, one might consult other Supreme Court opinions to determine what the Justices mean when they use the concept. The most logical cases to canvass comprise the Court's Title VII ${ }^{49}$ jurisprudence because Batson's proce-

set the fire could have burned any structure, but had chosen the black church, perhaps for subconscious reasons. Easley stated, "Sometimes .... we get so insensitive that we don't realize that some decisions are based on race." Robyn Meredith, Mixed Opinions About Role of Racial Hatred, N.Y. TMES, June 23, 1996, at A14.

46. See Hernandez, 500 U.S. at 371-72.

47. Fantastic or implausible explanations may seem more obviously to be intentional coverups than accounts unrelated to the facts of the trial. The latter could well be credible even though not trial related, whereas the former are, by definition, incredible.

48. See text accompanying notes $22-23$ supra.

49. 42 U.S.C. $\$ 2000$ (1994) (Title VII of the Civil Rights Act of 1964). 
dural framework for assessing whether a peremptory strike violates the equal protection principle, and indeed the very term "pretext," are borrowed from Supreme Court opinions in employment discrimination cases arising under that civil rights law. 50

McDonnell Douglas Corp. v. Green ${ }^{51}$ was the first case that established the procedure later followed in Batson. The case involved an African American mechanic who participated in an illegal civil rights demonstration against the defendant company after he was laid off. 52 When the company later advertised for mechanics, Green applied; but McDonnell Douglas refused to rehire him, allegedly because of his involvement in the illegal demonstration..$^{53} \mathrm{He}$ sued, claiming race discrimination. ${ }^{54}$ The Supreme Court determined that Green had established a step-one prima facie case that the decision not to rehire him was racially motivated, in violation of Title VII, but that the company had met its step-two burden of stating a nondiscriminatory reason-Green's participation in the illegal demonstration-for its refusal to rehire him. ${ }^{55}$ The Court then remanded the case to give Green the step-three opportunity to prove that the company's stated reason for his rejection was in fact a pretext. ${ }^{56}$

The first point to observe is that the Court's opinion explicitly asserts that a pretext is "a coverup," 57 thereby treating it like its dictionary definition. The term "coverup" presumably implies a deliberate deception.

The remainder of the Court's discussion focuses on various kinds of circumstantial evidence from which one could infer that the company's true motivation for rejecting Green was racial discrimination and hence that its stated justification was a pretext. Evidence that white employees involved in comparably serious acts were not treated the same as Green could be "[e]specially relevant" in determining the sincerity of the proffered explanation for refusing to rehire Green. ${ }^{58}$ Also relevant to establishing pretext could be evidence that the company had engaged in discriminatory employment practices against Green or other minorities, such as the company's

50. See Batson v. Kentucky, 476 U.S. 79, 94 n.18, 96 n.19, 98 n.21 (1986) (indicating that aspects of establishing a Batson claim borrow from Title VII jurisprudence); Sutphen, supra note 20, at 490 (noting that lower courts determining the validity of peremptory strikes "rely on the Title VII burden-shifting framework originally laid out by the Supreme Court in McDonnell Douglas Corp. v. Green[, 411 U.S. 792 (1973)]").

51. 411 U.S. 792 (1973).

52. See id. at 794-95.

53. See id. at 796.

54. See id. at 797.

55. See id. at 802-03.

56. See id. at 804-05.

57. Id. at 805.

58. Id. at 804 . 
treatment of Green while employed or its response to his legal civil rights advocacy. ${ }^{59}$ Alternatively, such evidence of racial discrimination could lead the court to conclude not that the asserted reason was false, but rather that it was not the sole reason for refusing to rehire Green.

In these latter instances, it is not entirely clear that the Court is treating pretext as an overt, deliberate lie. It is possible that the company's motivation was mixed-in which case the rationale offered would not be a lie-or that it was guilty of harboring unconscious racism. ${ }^{60}$ Perhaps the company, which is unlike the striking attorney in a peremptories situation because it is a multiperson organization and not a single individual, ${ }^{61}$ was not "aware" that, as a collective entity, it treated its minority employees differently than its other employees.

In short, the types of evidence that the Court indicates may be used to establish pretext do not point to a monolithic view of the concept. As in the peremptories cases, the Court's treatment of pretext in its Title VII jurisprudence also permits findings of pretext that do not equate to findings of conscious, deliberate deception. It seems wise to assume that, at least on occasion, those accused of offering pretextual justifications may not have purposefully lied about their motivations or even been aware of their true motivations.

\section{The Mens Rea of Pretext in the Peremptories Context}

As we have seen, at least three possible states of mind could be associated with findings of pretext in a peremptories case. First, the errant attorney may have deliberately lied in order consciously and intentionally to cover up a race or sex-based strike. Second, the attorney may have lied to himself when he offered his pretextual explanation, covering up his own unconscious race or sex-based motivation for striking the prospective juror in question. Third, despite the finding of pretext, the attorney may have offered an honest account of his reason for the strike. In this latter instance, the judge finding pretext may have simply been wrong about the attorney's subjective state of mind, given the available objective, circumstantial evidence. Or the attorney may have had mixed motives, one of which was the race or sex of the venireperson, but the other of which was genuinely proffered yet not accepted by the judge.

How deserving of reproach is the attorney in each of these circumstances? Certainly the scienter with which the individual acted is relevant in determining whether punishment is warranted. One who deliberately de-

59. See id. at 804-05.

60. See notes 41-45 supra and accompanying text.

61. See notes 79-82 \& 103 infra and accompanying texts. 
ceived the court in order to hide unconstitutional conduct appears more deserving of opprobrium than one who unwittingly misrepresented his own unconscious motivation. Thus, as a point of departure, I will use "mens rea," or culpable mental state- the established structure for appraising blameworthiness in criminal law - to evaluate culpability in this context. ${ }^{62}$

Comparing the states of mind found in pretext rulings to the categories of mens rea usually encountered in criminal law, the situation in which an attorney deliberately misled the court correlates with criminal intent or purpose. ${ }^{63}$ On the other hand, one who unwittingly misrepresented his motivation did not intend to mislead the court. To the extent he was found to have done so, he was really guilty of lying to himself. That is, he was unaware that he was misrepresenting his true motivation to the court. In criminal law terms, if he was nevertheless aware that there was a significant risk that he was misleading the court, he might be considered reckless. ${ }^{64}$ And if he should have been aware of such a risk but was not, he might be considered negligent. 65 If the circumstances were sufficiently indicative of an impermissible motive to strike such that the trial court was able to spot this possi-

62. Cf. Guardians Ass'n v. Civil Serv. Comm'n, 463 U.S. 582, 597 n.20 (1983) ("It is not uncommon in the law for the extent of a defendant's liability to tum on the extent of his knowledge or culpability.").

63. According to the Model Penal Code, a person acts "purposely" when "it is his conscious object to engage in conduct of [a particular] nature or to cause [a particular] result." MODEL PENAL CODE $\$ 2.02(2)$ (a)(i) (1962). The traditional view of criminal intent encompassed both "purpose, aim, or design" and knowledge, but the modern view is to distinguish knowledge from intent as purpose. See WAYNE R. LAFAVE \& AUSTIN W. SCOTT, JR., CRIMnAL LAW § 3.5, at 218 (2d ed. 1986).

64. According to the Model Penal Code, a person acts "recklessly" when "he consciously disregards a substantial and unjustifiable risk" that his conduct is of the proscribed nature or will result in the proscribed result. MODEL PENAL CODE $\S 2.02(2)(c)$. In criminal law generally, the term "recklessness" has not been used consistently. See LAFAVE \& SCOTT, supra note 63, $\$ 3.7$, at 232 n.5. Despite its differing usages, recklessness usually includes both subjective and objective elements: The actor must subjectively appreciate the probable consequences or nature of his act, and the conduct must objectively fall below the standard of conduct that a reasonable person would observe in the circumstances. See Robin Charlow, Wilful Ignorance and Criminal Culpability, 70 TEX. L. REV. 1351, 1377-80 \& nn.117-30 (1992). In short, recklessness is usually "conscious risk creation." Id. at $1378 \&$ n. 122 .

65. According to the Model Penal Code, a person acts "negligently" when "he should be aware of a substantial and unjustifiable risk" that his conduct is of the proscribed nature or will result in the proscribed result. MODEL PENAL CODE $\S 2.02(2)(d)$. As with recklessness, different definitions of criminal negligence are used in different cases, but all include some "expression of a required degree of risk which the defendant's conduct must create" and "an expression that that conduct is to be judged by an objective reasonable man standard." LAFAVE \& SCOTT, supra note $63, \S 3.7(a)$, at 233 .

If it seems unlikely that an attorney could be reckless or negligent in offering a false explanation, we must remember that those charged with violating Batson are essentially "explaining and justifying their own professional conduct." People v. Hameed, 666 N.E.2d 1339, 1343 (N.Y. 1996), cert. denied, $117 \mathrm{~S}$. Ct. 704 (1997). In such a pressured circumstance, the subtle influence that the need to protect one's integrity might have on the lawyer's perception of his conduct is significant. 
bility, then presumably there was such a risk, and the striking attorney was reckless or negligent in offering the pretext.

In the third circumstance, where the attorney did not lie or misrepresent his motives, we must consider two permutations. First, the trial court might have been wrong about the attorney's subjective state of mind. In other words, the attorney neither deliberately lied nor unconsciously misled the court about his true motivation, despite the finding of pretext based on circumstantial evidence. He could not have lied purposefully, recklessly, or negligently because he did not lie at all.

Second, the attorney might have acted with mixed motives, one (consciously or unconsciously) discriminatory and the other not. When asked his reason for striking the potential juror, the attorney honestly offered his nondiscriminatory motive; yet perhaps armed with evidence of an additional discriminatory motive, the court found the honest explanation to be a pretext. This is a more complicated case for determining culpability. Was the attorney under an obligation to come forth with his discriminatory motive, given that he honestly stated a genuine, nondiscriminatory one? If so, one could posit that he bears some responsibility and that the level of his culpability depends on his awareness of his unstated discriminatory motive. On the other hand, if he is under no obligation to reveal his additional discriminatory motive, he is just like the attorney in the previous example: He neither lied nor misrepresented purposefully, recklessly, or negligently.

\section{DISCRIMINATORY INTENT}

\section{A. In Equal Protection Law Generally}

According to the Supreme Court, the essence of an equal protection violation is invidious governmental discrimination. ${ }^{66}$ Discrimination is not invidious unless it is motivated by a discriminatory purpose or intent on the part of the decisionmaker. ${ }^{67}$ The requirement of discriminatory purpose has been much discussed yet remains rather elusive. It may mean a number of different things. The Court has indicated that it means that a governmental decision was made "at least in part 'because of,' not merely 'in spite of,' its adverse effects" on individuals identified by their race, sex, national origin,

66. See Washington v. Davis, 426 U.S. 229, 239 (1976) ("The central purpose of the Equal Protection Clause of the Fourteenth Amendment is the prevention of official conduct discriminating on the basis of race."); Frontiero v. Richardson, 411 U.S. 677, 687-88 (1973) (opining that sexbased classifications, like those based on race, alienage, and national origin, are "inherently invidious" and must therefore be subjected to strict scrutiny to determine whether they violate the equal protection principle).

67. See Davis, 426 U.S. at 240. In An Interpretive History of Modern Equal Protection, 90 MICH. L. REV. 213, 285 (1991), Michael Klarman traces the evolution of equal protection doctrine and notes the Burger Court's focus on limiting legislative "inputs" such as discriminatory intent, as exemplified by the "prototypical legislative inputs decision, Washington v. Davis." 
or other special feature.68 The term "implies more than intent as volition or intent as awareness of consequences." 69 As one commentator described it, "[T]he Court [has] defined discriminatory intent to include only actions taken with the conscious aim of disadvantaging protected minority groups."70 This implies a high level of scienter, as that term is used in other areas of law, ${ }^{71}$ on the part of the decisionmaker.$^{72}$ Although some have argued that discriminatory purpose ought to include "unconscious" bias, such as unconscious racism, ${ }^{73}$ the Court does not appear to have accepted that definition. Moreover, action having a disproportionate adverse impact on one of the protected classes is not considered unconstitutional unless the cause of the impact is shown to be a discriminatory purpose or intent, a conscious aim to cause an adverse impact on that group. ${ }^{74}$

On the other hand, in his prominent article on the subject, Daniel Ortiz argues that, "[d]espite the doctrine's name, 'intent' often has little to do with purpose or motivation."75 Ortiz observes that the doctrine "largely fails, in fact, to regulate the inputs to the government decisionmaking process," such as purpose or motivation, and that it often actually evaluates the outcomes instead. ${ }^{76}$ Similarly, Justice Stevens, in a series of separate dissenting and concurring opinions, has advanced the view that "[t]he line between dis-

68. Personnel Adm'r v. Feeney, 442 U.S. 256, 279 (1979); see also Bush v. Vera, $116 \mathrm{~S}$. Ct. 1941, 1973 (1996) (Thomas, J., concurring) (applying this understanding of discriminatory intent to race-based electoral districting).

69. Feeney, 442 U.S. at 279 (citing United Jewish Orgs. v. Carey, 430 U.S. 144, 179-80 (1977) (Stewart, J., concurring)).

70. Pamela S. Karlan, Note, Discriminatory Purpose and Mens Rea: The Tortured Argument of Invidious Intent, 93 YALE L.J. 111, 112 (1983).

71. See note 63 supra.

72. See Karlan, supra note 70 , at 122 . Karlan observes that "the stringency of the current standard is due in large part to its development as a response to explicit racial distinctions designed to disadvantage blacks." Id. at 130. She argues that lesser levels of mens rea, commensurate with criminal law's knowledge, recklessness, and negligence, should be sufficient to establish that a governmental act violates the Fourteenth Amendment's antidiscrimination principle. See id. at 12128.

73. See Charles R. Lawrence III, The Id, the Ego, and Equal Protection: Reckoning with Unconscious Racism, 39 STAN. L. REV. 317, 322-23 (1987).

74. See Hernandez v. New York, 500 U.S. 352, 362 (1991) (declaring that "the impact of a classification does not alone show its purpose"); Village of Arlington Heights v. Metropolitan Hous. Dev. Corp., 429 U.S. 252, 264-66 (1977) (holding that a discriminatory purpose must at least be a "motivating factor" in a decision); Washington v. Davis, 426 U.S. 229, 242 (1976) ("Disproportionate impact is not irrelevant, but it is not the sole touchstone of an invidious racial discrimination."). But cf. Batson v. Kentucky, 476 U.S. 79, 93 (1986) (quoting Davis, 426 U.S. at 242, for the proposition that disparate impact may "demonstrate unconstitutionality because in various circumstances the discrimination is very difficult to explain on nonracial grounds," as in the case of total or seriously disproportionate exclusion of African Americans from jury service). (1989).

75. Daniel R. Ortiz, The Myth of Intent in Equal Protection, 41 STAN. L. REV. 1105, 1106

76. Id. at 1106-07. 
criminatory purpose and discriminatory impact is neither as bright nor as critical as the Court appears to believe." 77 He has also observed that the most probative evidence of intent is frequently "objective evidence of what actually happened rather than evidence describing the subjective state of mind of the actor."'78

When examining legislative or other governmental "group" activity, it is easy to see why confusion results from applying the concept of discriminatory intent. ${ }^{79}$ What, after all, was the purpose of or motivation for a group's action? ${ }^{80}$ In this context, examination of the kind of subjective intent that is crucial in areas like criminal law seems nearly impossible. ${ }^{81}$ Much equal protection case law, and consequently much equal protection analysis, focuses on legislative or other multiparty decisionmaking. ${ }^{82}$ Perhaps in part for that reason, the concept of discriminatory intent is confusing. And perhaps also for that reason, Ortiz observes that the Court's search for intent does not usually focus on the actual, subjective purpose or motivation of the decisionmaker (or decisionmakers).

77. Hernandez, 500 U.S. at $377-78$ \& n.1 (1991) (Stevens, J., dissenting) (citing Davis, 426 U.S. at 253-54 (Stevens, J., concurring)).

78. Davis, 426 U.S. at 253 (Stevens, J., concurring); see also Hernandez, 500 U.S. at $378 \mathrm{n} .1$ (Stevens, J., dissenting) (citing Davis, 426 U.S. at 253-54). Of course, evidence of "what actually happened" may be circumstantial evidence of purpose. See, e.g., Shaw v. Hunt, $116 \mathrm{~S}$. Ct. 1894, 1900 (1996) (noting that the "race-based motive" for legislative districting may be proved "either through 'circumstantial evidence of a district's shape and demographics' or through 'more direct evidence going to legislative purpose"' (quoting Miller v. Johnson, 515 U.S. 900, 916 (1995))). There may also be cases in which direct evidence of race-based purpose is available, although such a scenario occurs more infrequently. See, e.g., Bush v. Vera, $116 \mathrm{~S}$. Ct. 1941, 1974 n.2 (1996) (Thomas, J., concurring) ("[O]nce the State directly conceded that it intentionally used racial classifications to create majority-minority [electoral] districts, there was no need to rely on circumstantial evidence [to establish discriminatory intent].").

79. See Davis, 426 U.S. at 253 (Stevens, J., concurring) ("It is unrealistic . . to require the victim of alleged discrimination to uncover the actual subjective intent of the [collective] decisionmaker or, conversely, to invalidate otherwise legitimate action simply because an improper motive affected the deliberation of a participant in the decisional process.").

80. See Robin Charlow, Judicial Review, Equal Protection and the Problem with Plebiscites, 79 CORNELL L. REV. 527, 571 \& n.171 (1994) (noting the difficulty of ascertaining the collective intent of a body such as Congress); John Hart Ely, Legislative and Administrative Motivation in Constitutional Law, 79 YALE L.J. 1205, 1213-14 (1970) (arguing that "evidence of a sort available only to the Almighty would be needed" to ascertain the mixed motives of legislators); see also Shaw, 116 S. Ct. at 1917 (Stevens, J., dissenting) (expressing skepticism about "the value of motivational analysis as a basis for constitutional adjudication" because "legislative decisions are often the product of compromise and mixed motives"); Vera, $116 \mathrm{~S}$. Ct. at $1984 \mathrm{n} .23$ (Stevens, J., dissenting) ("Testimony by individuals is relevant, but hardly dispositive evidence of collective motivations.").

81. But see Karlan, supra note 70, at 120-21 \& nn.53-55 (arguing that courts look for legislative intent, despite the difficulty of doing so, by using "a fictitious construct" and that, however difficult such a search might be, the Supreme Court requires courts to undertake it in equal protection cases).

82. See id. at 120 ("[T] he intention of some group, whether a school board or a legislature, is at issue in almost every equal protection case."). 
Discriminatory intent may also be defined as the absence of an "equal regard" for the impact of a governmental measure on the affected group as compared with its impact on other groups. ${ }^{83}$ Such a lack of equal regard might be, at least partially, a subjective notion. In other words, although the decisionmaker may purposefully disadvantage one group, it is more probable that he is concerned differently with how his decision affects those like him as compared with how it affects others. When dealing with a large governmental body such as a legislature, the decisionmakers' subjective lack of equal regard might be more common, or at least more readily discerned, than their subjective intent to affirmatively disadvantage the affected group. This is because it is more likely that the governmental body did not consider equally the effect of its action on all groups than that it deliberately tried to produce an adverse discriminatory effect on one group..$^{84}$

However, the Court's admonition that action motivated by discriminatory intent involves something more than action taken "in spite of" its effect on a protected class ${ }^{85}$ makes it difficult to understand discriminatory intent as a lack of equal regard. Acting without regard to the impact on a disfavored group, or with regard that is different from the regard afforded to the impact on a favored group, overlaps with acting "in spite of" the effect on members of the disfavored group. Thus, even though the phrases are not exactly coterminous, the Court's admonition that actions taken in spite of their impact do not betoken discriminatory intent militates against considering lack of equal regard to be tantamount to discriminatory intent.

In sum, although the Court uses the term "intent" in describing the invidious discrimination necessary to establish an equal protection violation, it does not seem exactly clear that the Court actually searches for a subjective

83. See JOHN HART ELY, DEMOCRACY AND DISTRUST: A THEORY OF JUDICIAL REVIEW 8687 (1980) (explaining that the Equal Protection Clause imposes a "duty of virtual representation," pursuant to which the government must consider the interests of all potentially affected parties and not deny minorities "equal concern and respect"); Paul Brest, The Supreme Court, 1975 TermForeword: In Defense of the Antidiscrimination Principle, 90 HARV. L. REV. 1, 7 (1976) (speaking of "the phenomenon of racially selective sympathy and indifference"). Brest refers here to "the unconscious failure to extend to a minority the same recognition of humanity, and hence the same sympathy and care, given as a matter of course to one's own group." Brest, supra, at 7-8.

84. See Karlan, supra note 70, at 122 n.69 (arguing that "[t]he nonpurposiveness of many legislative acts which disproportionately burden minorities" results because legislatures often act on multiple motives and effectuate the discriminatory voices of their constituents); id. at 124 (contending that most legislative action does not consciously seek to burden minorities, but rather to further an "umbrella goal," such as the promotion of the general welfare); $c f$. id. at $123 \mathrm{n} .70$ (arguing that the "but for" nature of the discriminatory intent requirement does not readily allow for findings of discrimination when the government intends to disadvantage one group at the same time that it seeks to advantage a difierent group); Lawrence, supra note 73, at 322 (stating that "a large part of the behavior that produces racial discrimination is influenced by unconscious racial motivation" rather than by self-consciously intentional or randomly unintentional motivation).

85. See Personnel Adm'r v. Feeney, 442 U.S. 256, 279 (1979) (distinguishing acts done "because of" their adverse effect from those done "in spite of" such an effect). 
human intention. Precisely what it does look for is also not clear. However, the Court does seem to be searching for something more than a disparate impact on or a lack of due regard for some protected class or an unconscious bias against the group's members.

\section{B. In Peremptories Cases}

The Court has recognized, in a series of cases beginning with Batson, that peremptory challenges to the seating of petit jurors may violate the equal protection principle. ${ }^{86}$ Here, as in all other equal protection contexts, the Court will not acknowledge a constitutional violation unless there is proof of discriminatory intent. ${ }^{87}$ In peremptories cases, proof of discriminatory intent means proof that a prospective juror was struck "because of" her race ${ }^{88}$ or sex. ${ }^{89}$ However, here the phrase "because of" race or sex does not appear to require a purpose to disadvantage the prospective juror because of her race or sex, as would be required in other equal protection cases, but simply a purpose to use race or sex as the basis for the strike. ${ }^{90}$

Moreover, unconstitutional discriminatory peremptory challenges arise in an unusual setting. Here, unlike an equal protection case challenging an act of a legislature or other multimember governmental body, a court reviews the conduct of a single actor. ${ }^{91}$ In the context of peremptory strikes, it seems more reasonable to look for subjective intent, as one does in criminal law when examining the motive or intent of an individual transgressor. What did the party who exercised the peremptory challenge mean to do? What was his personal, subjective motivation (or motivations) for the strike?

Professor Ortiz argues that, even in this context, the Court does not examine subjective purpose or intent. ${ }^{22}$ According to Ortiz, in a jury selection case involving allegedly discriminatory peremptory challenges, a criminal

86. See, e.g., Purkett v. Elem, 514 U.S. 765 (1995) (per curiam); J.E.B. v. Alabama ex rel. T.B., 511 U.S. 127 (1994); Georgia v. McCollum, 505 U.S. 42 (1992); Edmonson v. Leesville Concrete Co., 500 U.S. 614 (1991); Hernandez v. New York, 500 U.S. 352 (1991); Powers v. Ohio, 499 U.S. 400 (1991); Batson v. Kentucky, 476 U.S. 79 (1986).

87. See Batson, 476 U.S. at 93.

88. See id. at $96-98$ (finding a violation where the strike was exercised "on account of" race).

89. See J.E.B., 511 U.S. at 144-45 (finding a violation where the strikes were exercised "because of" the prospective jurors' sex).

90. See text accompanying notes 97-108 infra. It is possible that the Court considers it always to be to the disadvantage of a prospective juror (or to the disadvantage of his race or sex) to be excluded on the basis of race or sex. The Court's recent turn toward colorblindness as the equal protection norm might be interpreted to imply this.

91. But cf. Karlan, supra note 70, at 120 ("[T]he equal protection clause contemplates 'group offenses'; only the government, and not individuals, can violate it.").

92. See Ortiz, supra note 75 , at 1120 (concluding that, in jury selection cases, the Court's standards do not "focus precisely on the motivation of the jury selector" and that it is "simply wrong to say ... that these standards hinge on intent"). 
defendant trying to establish his prima facie case need not bring forth evidence of the prosecutor's actual discriminatory motivation in striking potential jurors. Rather, the defendant need only show that the prosecutor's selection procedures had a racially disparate impact and were susceptible to abuse, which all peremptory challenges are. ${ }^{93}$ Further, the prosecutor rebutting the prima facie Batson claim must come forth with "legitimate" reasons for his strikes and provide a "clear and reasonably specific explanation" of these reasons. ${ }^{94}$ In Ortiz's view, by placing a relatively light burden on the defendant-complainant that does not require actual proof of motivation and a relatively heavy burden on the prosecutor-striker to rebut this easily established prima facie case, the Court tests the "output" of the procedure (whether minorities were struck) rather than the "inputs" (whether the prosecutor-striker was motivated by race).${ }^{95}$ Is Ortiz correct?

My argument below refutes Ortiz's conclusion. However, it is worth noting that Ortiz wrote his article after the Court decided Batson, which used language suggesting that the equal protection principle might be applied in the way Ortiz maintains, but before the Court decided its Batson progeny, which seem to contradict Ortiz's point. As I will argue below, and as the cases themselves establish, Batson's progeny effectively alter the relative burdens of proof as Ortiz described them. ${ }^{96}$

\section{Batson v. Kentucky.}

Batson contains language implying that a subjective scienter of purpose to strike on account of race is required for a finding of discrimination. But other aspects of the opinion could be read to indicate that a more objective determination is being made. In one part of the opinion, the Batson majority states that the case reaffirms the principle that a "[s]tate's purposeful or deliberate denial to Negroes on account of race of participation as jurors in the administration of justice violates the Equal Protection Clause." 97 The reference to "purposeful or deliberate" sounds much like the subjective criminal law concept of purpose. ${ }^{98}$ On the other hand, the Court also notes that, in determining whether there has been invidious intent and thus unconstitu-

93. See id. at 1122-23.

94. Id. at 1123 (internal quotation marks omitted).

95. See id. at 1126.

96. See, e.g., Purkett v. Elem, 514 U.S. 765, 768-69 (1995) (per curiam) (indicating that the striking attomey's explanation need not be specific or trial related, but need only be grounded in something other than race or sex); Hemandez v. New York, 500 U.S. 352, 359-60, 362 (1991) (asserting that disparate impact on Latinos is insufficient to establish a Batson violation without proof of the prosecutor's subjective discriminatory motive).

97. Batson v. Kentucky, 476 U.S. 79, 84 (1986) (quoting Swain v. Alabama, 380 U.S. 202, 203-04 (1965)).

98. See note 63 supra and accompanying text. 
tional discrimination, objective factors such as "disproportionate impact" and the totality of the "relevant" facts and circumstances may be taken into account. 99

The Court seems to say that these latter factors are only to be used as evidence of subjective discriminatory intent, i.e., "purposeful or deliberate" action. ${ }^{100}$ As in other equal protection contexts, a significant discriminatory impact on the protected class, as well as other "relevant" factors, may raise the inference that there was a "purposeful or deliberate" denial of participation on account of race.

Moreover, two of the concurring opinions in Batson indicate an understanding of discriminatory purpose as a subjective concept. Justice White's concurrence describes the majority's opinion as searching for a very personalized "belief" on the part of the striking prosecutor "that no black citizen could be a satisfactory juror or fairly try a black defendant."101 Invoking another subjective characterization, Justice Marshall's concurrence criticizes the majority for placing upon trial courts "the difficult burden of assessing prosecutors' motives."102

It is fairly clear that the Justices in Batson meant to set forth a subjective concept of discriminatory intent. But it is arguable that they also meant to do so in other equal protection cases, cases which some do not read as definitively establishing discriminatory purpose as a subjective concept. ${ }^{103} \mathrm{Bat}$ son's discussion of discriminatory intent appears much like the Court's discussion of the construct in equal protection cases generally. The Court uses language that implies a subjective intent requirement yet, of necessity, considers factors, such as discriminatory impact, that do not necessarily establish subjective intent. In the Batson context, where the intent of a single individual is at issue, this technique appears more feasible. It is easier to conceive of the subjective aim of a single prosecutor to eliminate black jurors by striking them than it is to conceive of the subjective intent of a group as large as Congress to disadvantage blacks by passing a law that, while accomplishing some other end, also has a racially exclusionary effect. An analysis of Batson's progeny may help to resolve the "subjective versus objective" intent issue in the context of peremptory challenges.

99. See Batson, 476 U.S. at 93, 96-97.

100. See id. at 93 ("Circumstantial evidence of invidious intent may include proof of disproportionate impact." (citing Washington v. Davis, 426 U.S. 229, 242 (1976))).

101. Id. at 101 (White, J., concurring).

102. Id. at 105 (Marshall, J., concurring).

103. See, e.g., Hernandez v. New York, 500 U.S. 352, 377-78 \& n.1 (1991) (Stevens, J., dissenting) (blurring the line between purpose and impact); Ortiz, supra note 75, at 1106-07, 1111-19 (exploring how the supposedly subjective discriminatory intent requirement in several Supreme Court equal protection cases actually evaluates discriminatory impact). 


\section{Edmonson v. Leesville Concrete Co.}

In Edmonson v. Leesville Concrete Co., ${ }^{104}$ which extended the Batson principle to peremptory challenges in the civil arena, Justice Kennedy condemned the use of a "race generality"-a stereotypical idea of how jurors of a particular race will react to the evidence- to challenge potential jurors. ${ }^{105}$ He pointed out that race generalities derive from at least two motives: "open hostility" or "some hidden and unarticulated fear."106 According to Justice Kennedy, neither motive would overcome the equal protection violation that is inherent in utilizing a racial stereotype to exercise jury strikes. ${ }^{107} \mathrm{He}$ concluded that a litigant's beliefs about a prospective juror could be explored in a nondiscriminatory way without using race-based classifications. ${ }^{108}$

Several of these statements in Justice Kennedy's opinion appear to describe the striker's subjective state of mind, for example, references to the litigant's motives and beliefs. However, read carefully, the opinion is arguing that it is the automatic striking of potential jurors of a particular race based on racial stereotypes rather than the motivation behind either the act or the stereotype that must be condemned. The opinion leaves open the question of whether the search for discriminatory intent is a search for subjectively held racial stereotypes in the minds of litigants or a search for any automatic invocation of race as the grounds for a peremptory strike. But even in the latter case, the court would be looking for something subjective-the subjective goal of eliminating all blacks or women from the jury. In short, as it did in Batson, the Court in Edmonson appears to reiterate that it is the striker's subjective purpose or aim to eliminate from the jury members of a particular race or sex because of their race or sex that constitutes the requisite discriminatory intent. It is not simply what the striking attorney did, but what he had in his mind when he did it, that determines whether his actions were unconstitutional.

\section{Hernandez v. New York.}

Should there have been any doubt up to this point, the Court's discussion of proof of discriminatory intent in Hernandez makes it clear that the Justices meant to focus on the striking attorney's subjective state of mind. Writing for a plurality, Justice Kennedy explained why trial court findings on the issue of discriminatory intent should be entitled to deference. ${ }^{109}$ He noted that there will seldom be much evidence bearing on the credibility of the attor-

104. 500 U.S. 614 (1991).

105. See id. at 631 .

106. Id.

107. See id.

108. See id.

109. See Hernandez v. New York, 500 U.S. 352, 364-70 (1991). 
ney's purported explanation for a peremptory challenge and that the attorney's demeanor often provides the best evidence of his "state of mind."110 This reference indicates that the plurality intended to direct the court to peer, as closely as possible, into the striking attorney's mind, to examine his personal motivation in exercising the peremptory challenge.

Indeed, this very point occasioned Justice Stevens' dissent, in which Justice Marshall joined. There Justice Stevens argued that the Court-the plurality plus the concurring Justices-erred "in focusing the entire inquiry on the subjective state of mind of the prosecutor."111 He criticized the other Justices for requiring the defendant to "generate evidence of the prosecutor's actual subjective intent to discriminate," which he says neither Batson nor other equal protection holdings demand.112 The remaining seven Justices, including one dissenter, rejected this overt call to abandon the focus on the subjective state of mind of the striker, ${ }^{113}$ leaving us with a distinct understanding of discriminatory intent as an explicitly subjective concept in the peremptories context.

\section{Purkett v. Elem.}

Finally, in the Court's latest foray into peremptory challenges, Purkett $v$. Elem, a prosecutor said he struck two black veniremen because of their hairstyles: Each had a "mustache and a goatee type beard," and one had particularly bothersome "shoulder length, curly, unkempt hair."114 These features, he claimed, made them look "suspicious."115

The Supreme Court reversed the Eighth Circuit Court of Appeals and upheld the state appellate court's finding that there was no racial motive for the prosecutor's peremptory strikes, indicating that the state court's ruling "turned primarily on an assessment of [the prosecutor's] credibility."116 In other words, the Court accepted an examination of personal credibilitymeaning, in this context, a search for evidence that the prosecutor-striker was lying - as appropriate to a finding of no discrimination. ${ }^{117}$ As in the previous

110. Id. at 365 .

111. Id. at $378 \&$ n.1 (Stevens, J., dissenting).

112. Id. at 378 .

113. See id. at 365 (Kennedy, J., joined by Rehnquist, C.J., White, J., and Souter, J.,); id. at 372-75 (O'Connor, J., concurring, joined by Scalia, J.); id. at 375 (Blackmun, J., dissenting).

114. Id. Purkett v. Elem, 514 U.S. 765, 766 (1995) (per curiam).

115. Id. The prosecutor also said he struck one of the two because that individual had been held at gunpoint during a robbery and might therefore assume that all robberies, unlike the one under consideration in the case, require guns. See id. The Eighth Circuit accepted this justification and did not find the gun-related strike to be discriminatory. However, it ruled that the other strike, based solely on the appearance of the venireman's hair, was discriminatory. See id. at 767.

116. Id. at 769 (citing Batson v. Kentucky, 476 U.S. 79, 98 \& n.21 (1986)).

117. Interestingly, it was an appellate court, not a trial court, that held that there was no racial motive for the strikes. See id. at 775-76 (Stevens, J., dissenting). Thus, the Supreme Court ac- 
cases, the Court directed its inquiry to the striker's subjective state of mind.

Moreover, the per curiam opinion in Elem indicated that the Eighth Circuit erred when it improperly focused on the "reasonableness" of the asserted nonracial motive in the second step of its Batson analysis rather than on the "genuineness" of the motive. ${ }^{18}$ Once again, the Court concentrated its determination of discriminatory intent on the prosecutor's subjective state of mind: The Court effectively asked, "When he stated his reason, was he lying about his motivation?" rather than "Was his reason objectively sound?" Of course, the objective reasonableness of the purported justification is circumstantial evidence of its genuineness. However, the Court seemed to understand that the ultimate question is one of subjective honesty, not objective sensibility.

The fact that the determination of discrimination turned on whether the prosecutor was lying about his reason for the strike seems to indicate that, at least in the Batson context, it is indeed the subjective motivation of the actor that is crucial to the doctrine of discriminatory intent. For example, in Elem, the state court reasoned that because the attorney was credible when he explained why he struck the black veniremen-that is, because he was not lying-his subjective purpose for exercising the strikes was not a discriminatory intent to exclude blacks from the jury. ${ }^{119}$ Presumably, if the court found that the attorney lied in stating his reasons for striking the black veniremen, the court would have construed the lie as evidence of an effort to hide a discriminatory intent to exclude blacks. In either event, the focus on credibility as the determinative factor implies that the court is searching for the attorney's subjective state of mind when it rules on whether the requisite discriminatory intent exists.

On the other hand, a subjective notion of discriminatory intent does not necessarily follow from the Court in Elem highlighting the credibility of the striking attorney because an attorney who wants to conceal something other than unconstitutional discrimination might also lie about his reason for a strike. ${ }^{120}$ Although a lawyer might offer a pretextual reason in order to cover an embarrassing or foolish motive, the prospect of the court finding a Batson

cepted an assessment of credibility formed on the basis of a cold record, not on the actual demeanor of the prosecutor. In his dissent in Elem, Justice Stevens agreed that credibility was relevant. See id. at 775. He further argued that if the evidentiary record was sufficient, any appellate court-including the Eighth Circuit or even the Supreme Court-could determine whether a proffered reason for a strike was a pretext for discrimination. See id. at 775-76. According to Justice Stevens, an implausible or silly explanation could be so unbelievable that, even without observing the striker's demeanor, an appellate court could find it to be a pretext-that is, a lie-as a matter of law. See $i d$. at 776-77. Such a finding would have been appropriate in Elem, in Justice Stevens' view. See id. at 777.

118. See id. at 769.

119. See id.

120. See text accompanying notes $22-23$ supra. 
violation provides incentive for the attorney to reveal his true reason for such a strike. Yet one possible reason not to state honestly a nondiscriminatory reason is the fear that what one believes to be a neutral, nondiscriminatory reason will be ruled discriminatory nonetheless. For example, consider the position of the attorney in Hernandez. Suppose he struck two Latino veniremen because he was sincerely concerned that their proficiency in Spanish would impede their ability to accept the court interpreters' translation of the testimony. Afraid this genuine reason will be ruled unconstitutional discrimination on the basis of ethnicity or national origin, ${ }^{121}$ the attorney might lie and offer another explanation for the strikes, one which seems more likely to be ruled neutral, for example, the fact that the potential jurors he struck were the only ones with suspicious-looking facial hair. In this hypothetical case, Elem's subjective focus on the credibility of the striker's explanation might reveal that the explanation is a lie, but it would not indicate the striker's subjective discriminatory intent to exclude minorities from the jury because, as posited, he did not act with discriminatory intent. This state of affairs may result because pretext and discriminatory intent are often closely related, but not always coexistent. 122

Nevertheless, Elem is probably best read to confirm that, in determining discriminatory intent in a peremptories case, courts should look for evidence of a subjective purpose or motive to strike a prospective juror because of that person's race or sex. Elem appears about as definitive on this point as the peremptories cases that preceded it.

It thus seems clear that the Court intends to leave us with a subjective understanding of the concept of discriminatory intent in the peremptories context. Lower courts should look to whatever evidence exists as to the personal motivation of the attorney exercising the strike to determine whether he did so on account of the potential juror's race or sex. Not only does the Court say we should look for such subjective intent, but it appears, as far as possible, to have done so in each of its Batson-related decisions. Of course, a judge cannot put himself inside the mind of the striking attorney. As in any other legal context in which an actor's mental state is at issue, the court examines whatever objective evidence exists from which an inference of subjective intent can be drawn. These peremptories cases, of necessity, turn on circumstantial evidence, as do most other cases in which mental state is at issue. ${ }^{123}$ But despite these proof problems, it appears to be subjective motiva-

121. See Hemandez v. New York, 500 U.S. 352, 371-72 (1991) (expressly declining to rule on whether "a policy of striking all who speak a given language" might be found to be a pretext for racial discrimination).

122. See text accompanying notes 19-30 supra.

123. See Howard v. Senkowski, 986 F.2d 24, 31 (2d Cir. 1993) ("As with all other inquiries concerning mental state, the ultimate determination is an inference from all the pertinent circumstances, whether or not an acknowledgment [of the striking attomey's mental state] occurs."); see 
tion that is determinative, notwithstanding Professor Ortiz's conclusion to the contrary..$^{124}$

\section{The Mens Rea of Discriminatory Intent in the Peremptories Context}

To recap briefly: In equal protection law generally, the quest for discriminatory intent does not appear unquestionably to steer the courts into the minds of the relevant actors in search of an individual, subjective purpose to discriminate in some forbidden way. ${ }^{125}$ However, to the extent that the term "discriminatory intent" is used subjectively, the Court appears to look for conscious, deliberate discrimination, not unconscious motivation. ${ }^{126}$

In Batson cases, however, the Court more explicitly focuses on subjective motivation in determining whether a peremptory strike is discriminatory. Often, objective factors will be used to infer such an intent because that is the only evidence available. Courts may be more inclined to look for subjective intent when examining the conduct of a single actor, particularly when the actor is required to state his reasons for his behavior and when the credibility of his explanation may be assessed against the backdrop of other, similar conduct. For example, in determining the credibility of the proffered explanation for a challenged peremptory strike, the court could consider how other potential jurors of a particular race or sex were treated by the same attorney. ${ }^{127}$ Thus, it may simply be easier or more convincing for courts to use a subjective concept of intent in peremptories cases than elsewhere in equal protection analysis, though no more or less appropriate.

When the Court focuses on subjective motivation in a Batson case, there is some indication that it is looking for a scienter of purpose like that found in criminal law. ${ }^{128}$ Nevertheless, there appear to be several possibilities for the actual mens rea of an individual found to have the requisite discrimina-

also LAFAVE \& SCOTT, supra note $63, \S 7.7$, at $644-45$ (discussing how subjective states of mind, such as intent, premeditation, and deliberation, may usually be determined from circumstantial evidence); Charlow, supra note 64, at 1359-60 \& nn.21-27 (explaining that criminal knowledge-a subjective state of mind like criminal intent-is usually established by objective circumstantial evidence).

124. See notes $92-96$ supra and accompanying text.

125. See text accompanying notes $66-82$ supra.

126. See text accompanying notes 66-78 supra.

127. See Edmonson v. Leesville Concrete Co., 500 U.S. 614, 631 (1991) (noting that a pattern of strikes against blacks in the venire might give rise to an inference of discrimination); Batson v. Kentucky, 476 U.S. 79, 96-97 (1986) (same); Senkowski, 986 F.2d at 25 (involving a claim that the reasons offered for challenging a black prospective juror were not credible in light of the prosecutor's acceptance of a white prospective juror with similar characteristics); Splunge v. Clarke, 960 F.2d 705, 707-09 (7th Cir. 1992) (finding a Batson violation where the prosecutor asked black prospective jurors different questions about racial partiality than he asked white prospective jurors and where a black woman's response to a question about burden of proof was treated differently than identical responses by white persons).

128. See text accompanying notes $97-98$ supra. 
tory intent to violate Batson's equal protection principle.

First, the striker may have consciously aimed to exclude prospective jurors on account of their race or sex. In that case, the scienter involved would be like criminal intent or the Model Penal Code's notion of "purpose."129

Second, the striker may have sincerely believed that he was excluding the potential juror on grounds other than those prohibited, even though the court, objectively assessing the evidence of subjective intent and not privy to the actual state of mind of the striker, concluded otherwise. In such a case, the striker's mens rea would not accord with the criminal notion of purpose or intent: It would not have been his conscious aim to exclude on a forbidden basis, nor would he have realized that he was doing so.

If the striker did not purposefully discriminate, there are at least two possible explanations for his behavior. The first possibility is that the court was correct: The striker believed that he was acting nondiscriminatorily, but was deceiving himself in this belief. That is, he acted with an unconscious discriminatory intent. ${ }^{130}$ In this case, his mistake about his intent could be indicative of a scienter resembling criminal recklessness or negligence. His state of mind would resemble recklessness if he were aware of the risk that he was excluding potential jurors on an unconstitutional basis. ${ }^{131}$ It would resemble negligence if he were unaware of this risk but the proverbial reasonable person would have been aware of it. That is, a negligent attorney should have been aware that his peremptory challenge could have resulted in impermissible discrimination. ${ }^{132}$

Note that in both of these situations I did not conclude that the striker could have acted with a less culpable mens rea than negligence. This is because I assume that a court making a finding of unconstitutional discriminatory intent assesses the facts as a reasonable person would. If a reasonable court concludes from the available evidence that invidious discrimination was apparent, presumably so would a reasonable person. And if the attorney were unaware that there was a significant risk that he was acting with an improper discriminatory purpose in a situation in which a reasonable person would have recognized such a risk, then the attorney was at least negligent.

The second possibility is that the court was wrong: The striker was not acting with any sort of discriminatory intent, unconscious or otherwise, and the court simply misread his motives. In this situation, the attorney could not

129. For criminal law definitions of purposeful behavior, see note 63 supra.

130. Although unconscious discriminatory intent is not supposed to be the basis for an equal protection violation, see text accompanying notes 66-78 supra, the hypothetical posited here describes a situation in which the court did not realize that the striking attorney's discriminatory intent was unconscious.

131. For criminal law definitions of recklessness, see note 64 supra.

132. For criminal law definitions of negligence, see note 65 supra. 
have discriminated deliberately, knowingly, recklessly, or negligently because he did not act with discriminatory intent at all.

Finally, if the Court does not limit its inquiry to the lawyer's subjective intent to discriminate, other mental states might accompany findings of discriminatory intent in the Batson and equal protection contexts. For example, although courts may be directed to look for objective bits of evidence that signal a subjective intent to discriminate, they may not really be expected to figure out what was in the striking attorney's mind. In Hernandez, a majority of the Supreme Court refused to recognize the dissent's position that the Batson analysis in fact focuses on objective evidence rather than subjective intent. ${ }^{133}$ Nevertheless, the Court may actually be deciding some equal protection cases in this way, ${ }^{134}$ and likewise, lower courts may be applying a more objective analysis in some individual cases. ${ }^{135}$

If courts are really making rulings of discriminatory intent on a more objective basis, then the culpability of an attorney exercising what is found to be an unconstitutional discriminatory strike should be quite different. In this circumstance, the court does not make any finding with regard to the striker's actual state of mind, and thus the finding of discriminatory intent does not even purport to address the striker's scienter. An attorney's liability in this case would be akin to strict liability: He could be held ethically or otherwise personally responsible for his conduct without even an implicit finding of scienter by the court.

\section{ETHICAL IMPLICATIONS OF FINDINGS OF PRETEXT AND DISCRIMINATORY INTENT}

Before beginning a discussion of the ethical implications of a Batson finding, it is worthwhile to remind the reader that the conduct in question is already condemned as an equal protection violation. The remainder of this article examines whether any additional sanction should inure personally to the attorney involved.

Whether offering a pretext or exercising a discriminatory peremptory strike ought to constitute an ethical violation depends, in part, on the purpose of the rules governing professional ethics, an issue beyond the scope of this

133. See Hernandez v. New York, 500 U.S. 352, $377-78$ (1991) (Stevens, J., dissenting) (arguing that discriminatory purpose can sometimes be proved by objective evidence).

134. See generally Ortiz, supra note 75 (contending that, in its practical application, the discriminatory intent doctrine focuses on the objective outcomes of rather than the subjective "inputs" to governmental decisionmaking).

135. See, e.g., People v. Tapia, 30 Cal. Rptr. 2d 851, 868 (Cal. Ct. App. 1994) (reversing a trial court because, "rather than determining whether the prosecutor challenged ... three [Hispanic] jurors because of [his own] genuinely held, valid and nondiscriminatory reasons, the [trial] court essentially asked itself whether it objectively thought [the three Latinos] would be good jurors"). 
article. But whether these acts should be violative of the ethical code or any other rules applicable to an attorney's conduct ${ }^{136}$ should also hinge, at least in part, on the scienter that accompanies the conduct. ${ }^{137}$ Culpability is normally tied to one's mental state. That is, we usually consider it harsh to punish someone for his acts alone without also taking into account his awareness of the wrongful nature of his conduct or the risk that his conduct was inappropriate, or at least the reasonableness of his failure to recognize that risk.

There are instances in which our legal system punishes even actions taken with due care, but these are the exception rather than the rule. ${ }^{138}$ In tort law, strict liability might attach to the manufacture of products widely disseminated to a public that assumes such products are safe and that is not in a position to determine otherwise. ${ }^{139}$ In criminal law, strict liability usually applies to regulatory matters, often similarly involving defective goods, such as tainted food or drugs, that are distributed to a wide sector of the public that cannot be expected to protect itself. ${ }^{140}$ Only if we decide that either stating a pretext or exercising a discriminatory strike raises considerations like those at issue in other strict liability contexts ought the system punish

136. The types of "other rules" contemplated here include rules of procedure and those that otherwise permit courts to monitor courtroom proceedings. See, e.g., Gordon, supra note 9, at 712 $\&$ nn.279-82 (discussing the imposition of a fine on an attorney under a local rule and federal statute for offering a pretext for racially motivated strikes). It might be possible that even criminal sanctions-for example, for perjury in the case of offering a pretext-could be considered in some cases, although perjury usually involves false swearing and it is not clear that the attorneys offering pretexts have taken the necessary oath. See, e.g., 18 U.S.C. \$ 1621(1) (1994) ("Whoever ... having taken an oath ... willfully and contrary to such oath states or subscribes any material matter which he does not believe to be true ... is guilty of perjury ...."); N.Y. PENAL LAW $\S 210.05$ (McKinney 1988) ("A person is guilty of perjury . . . when he swears falsely."); id. $\$ 210.00$ (defining "swear[ing] falsely" to mean "while giving testimony" or "under oath in a subscribed written instrument").

137. The A.B.A. Model Rules of Professional Conduct indicate that the "willfulness" of an attorney's conduct is a consideration in deciding whether to discipline the attorney for a violation of the Rules and in determining what the proper sanction should be. See MODEL RULES OF PROFESSIONAL RESPONSIBILITY Scope II 5 (1994).

138. See W. Page Keeton, Dan B. Dobbs, Robert E. Keeton \& David G. OWen, PROSSER \& KEETON ON THE LAW OF TORTS $\$ 75$, at 537 (5th ed. 1984) [hereinafter PROSSER \& KEETON] (describing strict liability as appropriate when applied to unusual or socially unreasonable activities that nonetheless offer advantages outweighing the risks); LAFAVE \& SCOTT, supra note 63 , $\$ \$ 3.8-3.8(a)$, at $242-46$ (discussing strict liability offenses and indicating that, despite these offenses, "crimes usually do require some fault"); .

139. See, e.g., Greenman v. Yuba Power Prods., Inc., 377 P.2d 897, 900-01 (Cal. 1963) (holding the manufacturer of a power tool strictly liable in tort for injuries to a user "to insure that the costs of injuries resulting from defective products are borne by the manufacturers ... rather than by the injured persons who are powerless to protect themselves").

140. See, e.g., United States v. Dotterweich, 320 U.S. 277, 280-81 (1943) (finding the Federal Food, Drug, and Cosmetic Act of 1938 to impose strict criminal liability for the sale of adulterated or misbranded articles because the sale of such items "touch[es] phases of the lives and health of people which, in the circumstances of modem industrialism, are largely beyond self-protection"). 
such behavior without any consideration of the actor's culpable mental state.

\section{A. The Ethics of Pretexts}

\section{Deliberate lies.}

Earlier sections of this article discussed some of the mental states that are likely to accompany the conduct in question. ${ }^{141}$ There are a number of different possibilities. The easiest on which to focus is the case of an attorney who purposefully states a pretext for his strike in a deliberate attempt to hide his true motives. This attorney has lied to the court. Surely this outright lie about a material matter is an ethical violation. ${ }^{142}$ Indeed, an attorney's "duty of candor" to the court is a moral duty imposed on counsel not only by ethical codes, but also by rules of procedure, statutory mandates, and good conscience. ${ }^{143}$

\section{Unintended pretext.}

Beyond this particular situation, things get less certain. For example, what of the attorney who states a pretext, but does not do so deliberately? Perhaps he acted out of unconscious racism. How are we to deal with an attorney who unconsciously desired to deny members of a particular race or sex seats on the jury and so offered what he honestly believed to be his reason for a peremptory strike, which an astute court then rules was a pretext for the attorney's unconscious discriminatory motive? As noted earlier, although this individual did not purposefully deceive the court and believed he was stating his genuine reason for the strike, he was probably either negligent or reckless in offering the pretext. ${ }^{144}$ Should we punish him if he did

141. See notes 62-65 \& 129-135 supra and accompanying texts.

142. See note 14 supra (discussing MODEL RULES OF PROFESSIONAL CONDUCT Rule 3.3(a)(1) (1992)).

143. See Burns v. Windsor Ins. Co., 31 F.3d 1092, 1095 \& n.5 (11th Cir. 1994) (stating that a lawyer "always has a duty of candor to the tribunal," but in that context, referring to a more limited duty to make only truthful, supportable claims in a pleading); see also ABF Freight System, Inc. v. NLRB, 510 U.S. 317, 323 (1994) ("False testimony in a formal proceeding is intolerable."); id. at 325-26 (Kennedy, J., concurring) ("[T] he government ought not to suggest . . . that one who violates his testimonial oath is no worse than the student who claims the dog ate his homework."); id. at 327-28 (Scalia, J., concurring) (describing the National Labor Relations Board's "unseemly toleration of perjury" in the case, expressing his distaste for lying under oath, and arguing that federal law enforcement agencies ought not to tolerate it); People v. Hameed, 666 N.E.2d 1339, 1342 (N.Y. 1996) (observing that "prosecutors are officers of the court, with a corresponding unqualified duty of scrupulous candor," and concluding that, for this reason, an oath is unnecessary in Batson inquiries (internal quotation marks omitted)), cert. denied, 117 S. Ct. 704 (1997); Thomas L. Shaffer, On Lying for Clients, 71 NOTRE DAME L. REV. 195, 208 (1996) (examining Charles Curtis' argument that " it is inadmissible to lie to the court' . . . because '[a] lawyer's duty to his client cannot raise [sic] higher than its source, which is the court" (quoting Charles P. Curtis, The Ethics of Advocacy, 4 STAN. L. REV. 3, 7 (1951))).

144. See notes 130-132 supra and accompanying text. 
wrong without knowing it, in a situation in which a reasonable person would have known?

The answer to this question depends on whether the relative weight we assign to zealous representation as opposed to absolute truthfulness tips the scale toward or away from sanctions. The factors militating in favor of ardent advocacy are on the side of the scale opposed to sanctions. If we hold advocates personally liable for actions taken in connection with litigation, in a situation in which they themselves are either not aware of the wrongfulness of their conduct or at best aware only of the risk of behaving unconstitutionally, then there will probably be a diminution in the zealousness of advocacy. An attorney concerned about the court's perception of strikes against members of a particular race or sex and faced with sanctions for a miscalculation will think twice about going forward with the strikes.

The weight of this particular consideration will depend on the importance we assign to peremptory challenges, a matter beyond the scope of this article. If they are not especially significant, the prospect of an attorney foregoing them will carry little weight. ${ }^{145}$ If, on the other hand, peremptory challenges are one of the cornerstones of our jury system and contribute markedly to the public's and the litigants' confidence in the legal order, ${ }^{146}$

145. See, e.g., Batson v. Kentucky, 476 U.S. 79, $107-08$ (1986) (Marshall, J., concurring) (arguing that peremptory challenges should be eliminated entirely in criminal cases due to their "inherent potential ... to distort the jury process by permitting the exclusion of jurors on racial grounds" and stating that, despite their ancient lineage, such challenges are "not of constitutional magnitude, and may be withheld altogether without impairing the constitutional guarantee of impartial jury and fair trial"); Minetos v. City Univ. of N.Y., 925 F. Supp. 177, 183-85 \& n.9 (S.D.N.Y. 1996) (barring the use of peremptory challenges altogether because they "per se violate equal protection" and are "an unnecessary waste of time and an obvious corruption of the judicial process"); Alschuler, supra note 10, at 169-70, 208-11 (concluding that peremptory challenges are unconstitutional and "ensure the selection of jurors on the basis of insulting stereotypes without substantially advancing the goal of making juries more impartial"); Broderick, supra note 10, at 421 (opining that because Batson "cannot abate the discriminatory use of the peremptory," the "sideshow[s]" occasioned by Batson rulings add costs to society without achieving any meaningful end, "except perhaps to rescue the peremptory from the extinction it deserves"); Carl H. Imlay, Federal Jury Reformation: Saving a Democratic Institution, 6 LOY. L.A. L. REV. 247, 269-70 (1973) (maintaining that, although the peremptory challenge was originally needed to screen jurors and ferret out bias, today it "is probably the single most significant means by which such prejudice and bias is injected into the jury selection system"); Nancy S. Marder, Beyond Gender: Peremptory Challenges and the Roles of the Jury, 73 TEX. L. REv. 1041, 1136 (1995) (concluding that peremptories are harmful because they limit the perspectives that are available to the jury-particularly in cases in which diverse perspectives are needed-and "teach negative lessons in a public forum about who is a full citizen"); see also Roberta K. Flowers, Does It Cost Too Much? A "Difference" Look at J.E.B. v. Alabama, 64 FORDHAM L. REV. 491, 500 (1995) ("Although the Court has continued to give lip service to the importance of the peremptory challenge, its actions elevating the juror's rights to serve on the jury, and disregarding the issues of difference, imply that the peremptory challenge's importance has declined.").

146. In recent opinions, eight Justices have lauded peremptory challenges as an important, if not vital, component of our jury selection system and legal tradition. For their statements, cited alphabetically by Justice, see Georgia v. McCollum, 505 U.S. 42, 57 (1992) (Blackmun, J.) (empha- 
then the downside of deterring attorneys from using them adds great weight to the side of the scale opposing sanctions.

The weight on the other side of the scale will depend on whether the pretext is offered to cover up discriminatory conduct, in this case, unconscious discriminatory conduct. If it is not, then the pretext is simply a reckless or negligent misrepresentation, and we must weigh the significance of rooting out reckless or negligent misstatements made to a court. There may be reasons to hold attorneys personally accountable for such nondiscriminatory but pretextual behavior. For example, if it is vital that advocates scrupulously honor their obligation to be truthful to the court, then perhaps we should hold lawyers personally accountable if they appreciate the risk that they are being untruthful but speak recklessly anyway. ${ }^{147}$ In this case, it is not clear how the scales of zealous advocacy versus scrupulous honesty should tip. ${ }^{148}$ But it seems hard to justify punishment when it is applied to

sizing "the contribution of the peremptory challenge to the administration of justice"); Batson, 476 U.S. at 118-21 (Burger, C.J., dissenting) (explaining the historical and other bases for concluding that the "the [peremptory] challenge is one of the most important of the rights in our justice system" (citing Swain v. Alabama, 380 U.S. 202, 219 (1965) (internal quotation marks omitted))); Powers v. Ohio, 499 U.S. 400, 409 (1991) (Kennedy, J.) (noting the "acceptance in our legal system" of preemptories); J.E.B. v. Alabama ex. rel. T.B., 511 U.S. 127, 147 (1994) (O'Connor, J., concurring) (reiterating the utility of peremptory strikes generally); Batson, 476 U.S. at 98 (Powell, J.) (recognizing "that the peremptory challenge occupies an important position in our trial procedures"); id. at 137 (Rehnquist, J., dissenting) (bemoaning the majority's restriction on "the historic scope of the peremptory challenge"); J.E.B., 511 U.S. at 163 (Scalia, J., dissenting) (describing the peremptory challenge as "a practice that has been considered an essential part of fair jury trial since the dawn of the common law"); Edmonson v. Leesville Concrete Co., 500 U.S. 614, 645 (1991) (Scalia, J., dissenting) (citing Holland v. Illinois, 493 U.S. 474, 484 (1990), for the proposition that justice will suffer if peremptories are abolished); and McCollum, 505 U.S. at 60-62 (Thomas, J., concurring in judgment) (admonishing that "black criminal defendants will rue the day that this Court ventured down this road that inexorably will lead to the elimination of peremptory strikes," and that "whatever the benefits were that this Court perceived in a criminal defendant's having members of his class on the jury, they have evaporated" (citation omitted)). Several commentators have noted the importance of peremptory challenges as well. See, e.g., Barbara Allen Babcock, Voir Dire: Preserving "Its Wonderful Power," 27 STAN. L. REv. 545, 555 (1974-1975) ("The symboliceducative, impartiality-promoting role of the peremptory challenge makes it central to the jury trial right."); Richard D. Friedman, An Asymmetrical Approach to the Problem of Peremptories?, 28 CRM. L. BULL. 507, 511 (1992) (arguing that peremptories are significant not only "in contributing to fairness itself," but also "in contributing to the perception of fairness. No system of challenges for cause can serve as well as peremptories the crucial function of giving the accused a strong sense that his jury is fair."); Ogletree, supra note 10, at 1140 ("[T] he best-indeed, after Batson, the only-justification for peremptory challenges is that the trial judge should not necessarily have the sole power to determine who can sit on a jury that itself exists because, in our legal system, some decisions should not be made by judges."). But cf. Babcock, supra note 10, at 1174-80 (arguing that peremptories should be retained, but that the procedures surrounding their use should be significantly modified so that they are not used as vehicles for discrimination on the basis of group identity).

147. For criminal law definitions of recklessness, see note 64 supra.

148. As Pamela Karlan points out, the culpability of the reckless individual stems from the fact that he "overweighs his own interests-the purpose of his acts-at the expense of abdicating his responsibilities to his fellows." Karlan, supra note 70, at 122 n.62. 
the negligent pretext-giver. ${ }^{149}$ In this latter case, the countervailing consideration relating to ardent advocacy could well outweigh the incentive-fortruth factor.

However, if an unintended pretext results from unconscious discriminatory intent, then we must decide an additional relevant factor: How important is it to wipe out all vestiges of potential discrimination? Those who consider it crucial might want to add substantial additional weight to the personal sanction side of the scale, ${ }^{150}$ not just as a deterrent, but also as a wakeup call to members of the legal profession to take heed of the significance of every potentially discriminatory action. But although the antidiscrimination factor is important, it does not seem so overriding as to warrant personally punishing individuals who do not act with conscious, invidiously discriminatory intentions. ${ }^{151}$ For one thing, the act of discrimination itself is sanctioned and corrected when the court finds an equal protection violation and disallows or otherwise remedies the improper peremptory challenge. Levying additional personal sanctions against the errant attorney would be the proverbial icing on the cake.

It might make sense to distinguish between those attorneys who were merely negligent in not appreciating the risk that they were stating a pretext for an unconscious discriminatory motive and those who were reckless. In any event, liability for reckless or negligent conduct should at least require that the pretext was offered to cover up unconscious discrimination. If the attorney incorrectly believes the pretext to be his true motive but is not covering up unconscious discriminatory intent, then no antidiscrimination factor weights the scale toward personal sanctions. Ultimately, however, the weight assigned to preventing unconscious discrimination is a matter of so-

149. For criminal law definitions of negligence, see note 65 supra. The culpability of negligent behavior stems from "failing to bring to bear one's faculties to perceive the risks that one is taking." Karlan, supra note 70, at 122 n.62 (quoting George P. Fletcher, The Theory of Criminal Negligence: A Comparative Analysis, 119 U. PA. L. REV. 401, 415 (1971)).

150. For an especially strong view on the antidiscrimination principle, see generally Barbara D. Underwood, Ending Race Discrimination in Jury Selection: Whose Right Is It, Anyway?, 92 COLUM. L. REV. 725 (1992). Underwood contends:

[E]ven if there were some statistical support for the view that jurors tend to be especially sympathetic to defendants of their own race, it would be profoundly wrong to enshrine any such view in our constitutional jurisprudence. The Constitution prohibits state legislatures, public employers, public universities, and a host of other institutions from acting on generalizations based on race, sex, or certain other suspect classifications, even when there is some statistical support for those classifications.

Id. at 732.

151. Cf. Karlan, supra note 70, at 119-20 (maintaining that criticism of criminal sanctions imposed on individuals for group crimes is inapposite to antidiscrimination jurisprudence because the Equal Protection Clause contemplates "group" rather than individual offenses and that liability in the antidiscrimination context "places no burden on the individual [state actors] who collectively violate[ ] the Fourteenth Amendment" because they are immune from suit). 
cial policy and not easily quantifiable. ${ }^{152}$

\section{Honest motives.}

In another scenario, the court was wrong in finding pretext and the attorney did not misrepresent his motives. It is difficult in this circumstance to conceive of a reason to hold the attorney personally responsible. He did not lie, nor did he have a culpable state of mind. Although strict liability might accrue here, such an outcome seems inappropriate. The usual instances in which strict liability applies involve acts that are in themselves bad, harmful, or wrongful, despite the possibly commendable mental state of the actor. ${ }^{153}$ Here, however, we are dealing with an act-not lying to the court-that in itself is not wrong or harmful.

How then would it arise that a court would find pretext when the attorney spoke truthfully? Could courts be so wrong? The answer probably depends on the strength of the courts' desire to root out improper discrimination. If courts take the antidiscrimination admonition very seriously and therefore err on the side of finding a Batson violation, ${ }^{154}$ the fact that the pretext determination depends largely on objective, circumstantial evidence of potential discrimination ${ }^{155}$ should account for some such instances of judi-

152. Cf. id. at 123-26 (arguing that knowing, reckless, and negligent discrimination may reflect "morally offensive indifference" or other culpable conduct on the part of the state).

153. See LAFAVE \& SCOTT, supra note $63, \S 3.8$, at 243 (indicating that legislatures may impose liability without fault where they believe "it important to stamp out the harmful conduct in question at all costs, even at the cost of convicting innocent-minded and blameless people"); PROSSER \& KEETON, supra note 138, § 75, at 536-37 (explaining that strict liability in tort covers individuals who are "not only charged with no moral wrongdoing," but who have not even departed "from a reasonable standard of intent or care," and that it applies where the activity "is unusual and abnormal in the community" and "the danger which it threatens . . . is unduly great"); see also United States v. Park, 421 U.S. 658, 671 (1975) (holding the chief executive officer of a company criminally liable for distributing adulterated food without proof of his personal participation in or knowledge of such conduct because "the public interest in the purity of its food is so great as to warrant the imposition of the highest standard of care on distributors" (quoting Smith v. Califomia, 361 U.S. 147, 152 (1959))); Greenman v. Yuba Power Prods., Inc., 377 P.2d 897, 900-01 (Cal. 1963) (holding the manufacturer strictly liable for injuries caused by a defective power tool and noting that strict product liability now encompasses a wide variety of products, besides unwholesome food, "that create as great or greater hazards if defective"); People v. Caddy 540 P.2d 1089, 1091 (Colo. 1975) (holding that violation of the speed limit law is a strict liability offense because, "as a matter of public policy," a driver must be charged "with the responsibility of ensuring that his vehicle is safe, so as to minimize the risk inherent in travel on our public highways").

154. The same consideration would arise where the alternate burdens of proof of the complainant and the striking attorney are so weighted as to lead toward finding Batson violations. See Ortiz, supra note 75, at 1122-24 (maintaining that the relative burdens of proof of the parties in a Batson context result in easier proof of equal protection violations than the burdens of proof imposed in other equal protection contexts); see also Joel H. Swift, The Unconventional Equal Protection Jurisprudence of Jury Selection, 16 N. ILL. U. L. REV. 295, 330 \& n.246 (1996) (noting that, in their oscillating approach to peremptory challenges, courts have sometimes erred on the side of finding that facially neutral reasons were pretexts).

155. See notes 123 \& 133-135 supra and accompanying texts; see also State v. Cruz, 857 P.2d 
cial error. ${ }^{156}$ Courts are guessing at the content of the striking attorney's thoughts, something which they simply cannot know and about which there will be precious little evidence. ${ }^{157}$ This fact, coupled with the ostensibly incriminating objective evidence that is sometimes available, could result in judicial error. ${ }^{158}$

Although there seems to be little reason to hold the attorney in this situation liable, it will be nearly impossible to determine when this state of affairs exists. Surely the trial judge, having made the pretext determination, will not decide that the attorney involved should be held harmless because the judge himself was (or might have been) wrong. Hence, if we want courts to err on the side of rooting out instances of possible discrimination, judges must give the attorneys involved the benefit of the doubt when it comes to their personal responsibility for the ensuing findings of pretext. ${ }^{159}$

1249,1253 (Ariz. 1993) (en banc) ("[W]here . . the state offers a facially neutral, but wholly subjective, reason for a peremptory strike, it must be coupled with some form of objective verification before it can overcome the prima facie showing of discrimination.").

156. See notes 133-135 supra and accompanying text; see also Underwood, supra note 150, at 770 (observing that, whereas "some instances of illegal discrimination [undoubtedly] escape detection, and in other cases courts improperly find discrimination where none exists," this problem is not unique to the context of jury selection).

157. See Michael J. Raphael \& Edward J. Ungvarsky, Excuses, Excuses: Neutral Explanations Under Batson v. Kentucky, 27 U. MICH. J.L. REFORM 229, 266 (1993) ("[T]he trial judge cannot read the prosecutor's mind to ascertain without doubt whether an explanation is truthful or merely a sham."); note 123 supra and accompanying text.

158. See Raphael \& Ungvarsky, supra note 157, at 266-67 ("Any reasonable judicial test that still retains peremptory challenges ... will reject some legitimate strikes that appear highly suspicious."); see also Underwood, supra note 150, at 773 ("[I]f the articulated reasons strike the reviewing court as implausible, that implausibility will tend to support a finding that the articulated criteria are not genuine, but instead are merely pretextual.").

Pemberthy v. Beyer, 19 F.3d 857 (3d Cir. 1994), illustrates this point. In Pemberthy, which was tried before Batson, the prosecutor claimed to have struck all Spanish-speaking venirepersons because of concern about their ability to accept the translations offered in court of wiretap evidence involving alleged colloquialisms and cryptic drug references. See id. at 859-63. The state appellate court accepted this explanation when a Batson issue was first raised on appeal. See id. at 862. Later, on a petition for habeas corpus, the district court held a hearing at which it questioned the prosecutor about his reasons for the strikes. See id. 862-63. It then identified seven factors that led it to conclude that the prosecutor's professed reasons were pretexts for national origin discrimination and that the real reason was "prejudice against Latinos." Id. at 863-64, 866 n.8. On appeal, the circuit court examined these evidentiary factors and concluded that there was ample evidence to suggest "that the prosecutor's professed concern about translation issues was not a pretext," and therefore that the state court determination in that regard should not have been rejected. Id. at $866-$ 68.

159. Perusing the relevant reported decisions might leave the impression that it takes very little to raise a Batson claim and, indeed, establish a prima facie case of a violation. Since a peremptory directed against a prospective juror of any race, sex, or national origin may be the basis for a claim of discrimination, and since a single peremptory strike may give rise to a claim, it would seem that virtually every strike could occasion a charge of discrimination and cause the court to require an explanation from the striker. If the burden of establishing a prima facie case is as simple as stating "a white" or "a black" or "a man" or "a woman" was struck, and if the striker then has an 
If, on the other hand, courts are not quick to find discrimination and hence pretext, ${ }^{160}$ and especially if they are very reluctant to do so, ${ }^{161}$ such judicial errors will be unlikely to occur, and personal sanctions will rarely attach to the wrong party. A thorough study of courtroom practice would be necessary to reach a definitive conclusion as to how often this problem arises, and even then, there may not be a uniform trend among the courts in this regard.

\section{Mixed motives.}

The last type of pretext implicates attorneys with mixed motives: an unstated motive that is consciously or unconsciously discriminatory and a nondiscriminatory motive that is honestly offered. The court smokes out the pretext and must then decide whether to impose personal sanctions for the concealed discriminatory motive. As noted earlier, in this instance, culpability should probably depend on the attorney's obligation to come forth with the unstated reason. Even under existing rules of professional conduct, it might be unethical to state only one of several reasons for an action if doing so constitutes a "misrepresentation."162 And existing ethical rules aside, it seems clear that courts in a Batson setting expect striking attorneys to tell all when it comes to their motives. Because the whole purpose of the inquiry is to determine whether discrimination is afoot, any attempt to mask it by omission seems rather obviously inappropriate. Hence, the attorney offering his honest reason but not offering his discriminatory reason should probably be

uphill hurdle to overcome the implication of discrimination, then surely the attorney now saddled with the burden of explanation should not be personally sanctioned for failing to be persuasive in his or her defense.

However, there ought to be something about the surrounding circumstances that raises an inference of discrimination before the striker is asked to justify his or her action. For example, in a predominantly white district, the simple act of striking the first white person to be considered for the panel would not normally, in and of itself, raise such an inference. However, if the context of the case makes the striking of a white person suspicious - for instance, if the defense counsel for a black defendant charged with attacking whites for racially motivated reasons exercises the strikethen perhaps the court would have reason to find a prima facie case of discriminatory intent and require a nondiscriminatory explanation. It often appears to take more than one peremptory challenge to raise such an inference, at least when nonminorities are struck. Thus, although at first glance the Batson claimant appears to bear a different and easier burden of proof than claimants in other discrimination cases, in actuality, his burden should be the same.

160. The proposition stated would also apply if the relative burdens of proof for each side are weighted against finding Batson violations, for the converse of the reason stated in note 154 supra. See also Swift, supra note 154, at 330 ("[T]he [Supreme] Court has moved from preference for the [peremptory] challenge, quickly through preference for the Equal Protection Clause, and back to preference for the challenge.").

161. See, e.g., Howard v. Senkowski, 986 F.2d 24, 31 (2d Cir. 1993) (refusing to "accept the premise ... that prosecutors will readily disregard the obligations of their office and violate the requirements of an oath by swearing false denials of racial motivation").

162. For a description of rules prohibiting attorneys from making misrepresentations to a court, see note 14 supra. 
held accountable for his unstated intent. The nature of the attorney's accountability will depend on whether the unstated intent is known (conscious) or not known (unconscious) to him and should then follow the same analysis as above.

\section{B. The Ethics of Discriminatory Strikes}

One could simply apply the above analysis wholesale to the various possible instances of discriminatory strikes and reach the same conclusions as were reached above with regard to findings of pretext accompanied by mental states of intent, recklessness, negligence, and nonculpability. However, it is less clear that a finding of unconstitutional discrimination-even intentional discrimination-should engender ethical or other personal sanctions than that a finding of pretext should. There are at least four reasons why this might be so.

First, from a practical standpoint, it could be said that lying is a more serious breach of courtroom decorum than discriminating, even if discrimination is both repugnant and unconstitutional. Although some may argue that, on occasion, a zealous advocate should be permitted to dissemble in court, ${ }^{163}$ most would probably agree that intentional lying to a court is a serious transgression. Moreover, as a practical minimum, courts must be able to rely on the veracity of propositions presented by counsel, or else the system would become close to unworkable. It is not surprising that our codes of professional responsibility universally condemn making misrepresentations to a court. ${ }^{164}$

But what of the morality of discriminating? In contrast to the strict rules against misrepresentation, most legal ethics codes do not contain rules barring discrimination of any sort. ${ }^{165}$ It could be that the immorality of race and sex discrimination entered the collective consciousness more recently and that codes have not yet absorbed the concept. ${ }^{166}$ Or it could be that we do not find misrepresentation and discrimination to inhabit the same moral plane and will continue to treat lying as an unmistakable infraction while we equivocate over the significance of discriminating.

163. See, e.g., MONROE H. FREEDMAN, UNDERSTANDING LAWYERS' ETHICS 111 (1990) (arguing, in reference to a criminal defense lawyer's presentation of known perjurious testimony, that the lawyer's duty to "be candid with the court ... must give way" to both his duty to provide effective assistance and his duty of confidentiality when these multiple obligations conflict). But cf. id. at 213-15 (noting differences between the obligations of prosecutors and those of other lawyersspecifically, criminal defense lawyers-and concluding that prosecutors' ethical standards are different from those applicable to others).

164. See note 14 supra.

165. For a description of the 18 state antidiscrimination provisions, see note 13 supra.

166. For one suggestion that we alter our treatment of discrimination in the professional context, see Gordon, supra note 9, at 712-17 (proposing that the A.B.A.'s Model Rules of Professional Conduct be amended to include a specific rule barring discrimination in jury selection). 
A second practical argument for treating lying and discriminating differently in the courtroom context involves the problem of unconscious racism. It may be more difficult for an individual to tell when he is discriminating than to discern when he is lying. An attorney might not always know when he is making a misrepresentation; the proffer of an unconscious pretext serves as an example. ${ }^{167}$ However, the boundaries of discrimination may be even fuzzier than the demarcation between truth and falsity. We are accustomed to pondering the issue of truth; we are familiar with asking ourselves whether we are speaking truthfully, having been taught to do so from early childhood. But we may be less familiar with deciding whether we are discriminating against a particular race or sex.

Whether this distinction between lying and discriminating is accurate as a general matter is debatable; however, in the specific context of Batson rulings, the two determinations are not that different. An attorney is probably not any more likely to know whether he is lying about his reason for striking a venireperson than he is to know whether he struck that person on account of the person's race or sex. Those inclined to deceive themselves about their own unconscious discriminatory motives will probably also offer a correspondingly unconscious pretext for their unconscious discrimination. Given the close connection between pretext and discrimination in most all cases, ${ }^{168}$ a finding of discrimination is usually tantamount to a finding of pretext.

A third, more controversial argument for treating the two acts differently - one based on social norms rather than on practical considerationsasserts that lying is more morally abhorrent than discriminating. But it is not at all clear that this proposition has any discernible truth, and it would be difficult to establish convincingly that our society generally subscribes to it.

Although our public culture undoubtedly teaches us that it is wrong to lie, ${ }^{169}$ it may not be as widely understood or accepted that discrimination is immoral. We cannot even agree whether the possible limited admonition against discrimination contained in our Constitution, which applies only to the government and not to individuals, is a statement that discrimination is always or only sometimes wrong. ${ }^{170}$ Moreover, we seem to recognize many

167. See text accompanying notes $41-45$ supra.

168. See text accompanying notes 19-30 supra.

169. See SisSELA BOK, LYING: MORAL CHOICE IN PUBLIC AND PRIVATE LIFE 18 (1978) (referring to "the centrality of truthfulness" and describing deceit as one of "the two forms of deliberate assault on human beings").

170. For example, many people-including Supreme Court justices-disagree over whether "reverse discrimination" occasioned by certain affirmative action policies violates the Equal Protection Clause. See Jesse H. Choper, Continued Uncertainty As to the Constitutionality of Remedial Racial Classifications: Identifying the Pieces of the Puzzle, 72 IOWA L. REv. 255, 255 (1987) (reviewing diverse positions of then Supreme Court justices on the issue of reverse discrimination and noting the intense controversy over the constitutionality of using racial classifications to remedy prior racial discrimination); see also Michel Rosenfeld, Decoding Richmond: Affirmative Action 
instances in which discrimination could be justified. For example, under the Constitution, race-based discrimination may be acceptable for remedial purposes, ${ }^{171}$ and sex-based discrimination may be permitted when there is an important reason for it. ${ }^{172}$

On the other hand, it does not take much effort to identify numerous instances in which we do not practice what we preach about lying. ${ }^{173}$ Despite the superficial cultural taboo against telling falsehoods, lying of all sortswell-intentioned and otherwise-is rampant and largely condoned or excused. ${ }^{174}$ I would not relish being asked to prove that our society is any better about truthtelling than it is about not discriminating. Furthermore, many now feel that, just as acts of misrepresentation need to be explained and justified, so do acts of race and sex discrimination.

and the Elusive Meaning of Constitutional Equality, 87 MiCH. L. REV. 1729, 1729 (1989) ("[T]he Justices [have] been bitterly divided on whether particular forms of affirmative action are compatible with constitutional principles of equality."); Kathleen M. Sullivan, Comment, Sins of Discrimination: Last Term's Affirmative Action Cases, 100 HARV. L. REV. 78, 78 (1986) ("Some affirmative action measures have been voted up and some down, but through it all, the Supreme Court has permitted no decisive victory to either side, nor dealt either side a decisive defeat."). Compare ELY, supra note 83, at 170-72 (opining that affirmative action policies imposed by whites to benefit blacks are constitutional), and Robert Allen Sedler, Racial Preference and the Constitution: The Societal Interest in the Equal Participation Objective, 26 WAYNE L. REV. 1227, 1259 (1980) ("[T]he use of racial preference to advance the equal participation objective is constitutional because it is related to achieving 'genuine equality' between blacks and whites in American society."), with Michael J. Perry, Modern Equal Protection: A Conceptualization and Appraisal, 79 Colum. L. REV. 1023, 1043-45 (1979) (discussing ways in which "preferential treatment" for one race "indirectly weakens the force of the principle of the moral equality of the races" that underlies the Equal Protection Clause).

171. See City of Richmond v. J.A. Croson Co., 488 U.S. 469, 509 (1989) (stating that if city governments offer evidence of systematic past discrimination, remedial action in the form of preferences for minority contractors might satisfy strict scrutiny); Fullilove v. Klutznick, 448 U.S. 448, 482-84 (1980) (upholding remedial racial preferences on the ground that remedies for past discrimination need not be color-blind).

172. See, e.g., Rostker v. Goldberg, 453 U.S. 57, 78-79 (1981) (permitting draft registration of males but not females because only males were eligible to serve in combat); Personnel Adm'r v. Feeney, 442 U.S. 256 (1979) (upholding a state decision to reward veterans with civil service job preference even though it resulted in the substantial exclusion of women from most civil service positions).

173. See, e.g., Bok, supra note 169 , at $73-241$ (identifying common excuses and justifications for lying and exploring the justifications for lying in a crisis, to liars, to enemies, to protect peers and clients, for the public good, in social science research, in a paternalistic context, and to the sick and dying).

174. See id. at xvi-xviii (observing that, in many professional and other contexts, such as medicine, law, journalism, government, the social sciences, advertising, law enforcement, and intelligence gathering, "deception is taken for granted when it is felt to be excusable by those who tell the lies and who tend also to make the rules" and that "reasons to lie occur to most people quite often"); see also Elaine Sciolino, A Rigidly Flexible Notion of Truth, N.Y. TIMES, July 20, 1997, at E5 (observing that, despite its "bright line" rule against lying, "[t]he military ... is often as inclined as other employers to tolerate, encourage and sometimes require people to lie"); Jeff Stryker, Lies, Justice, the American Way, N.Y. TMMES, Dec. 29, 1996, at E10 (exploring the pervasiveness of lying in American culture). 
Even if one could show that lying is more readily recognized as a cultural taboo than is discrimination, this begs the question of whether that is because lying is more repugnant or because the prohibition against it is of older vintage. In short, since one cannot definitively ascertain whether lying is morally worse than discriminating, this particular distinction should not serve as a justification for dealing differently with acts of lying than with acts of discrimination. ${ }^{175}$

However, there is a fourth and perhaps more significant reason to distinguish between the ethics of stating a pretext and those of exercising a discriminatory peremptory strike: It may at least be morally understandable, if not legally excusable, to make distinctions among potential jurors on the basis of their race or sex. To understand why this is so, remember that one of the reasons that individuals on both sides of the political spectrum have expressed concern over the Court's decisions limiting peremptory challenges on equal protection grounds relates to the nature and supposed purpose of peremptories. Peremptories are intended, in part, to eliminate jurors who might be less receptive to one party in a case, ${ }^{176}$ but whose bias could not be sufficiently established to meet the requirements of a challenge for cause. ${ }^{177}$ Furthermore, some argue that peremptories need to be entirely discretionary in order to achieve this purpose ${ }^{178}$ because suspicions about the probable leanings of a particular venireperson are often based on generalizations about

175. As a colleague pointed out to me, it might be said, conversely, that our society now considers it worse to discriminate than to lie. I do not address this possibility in the text because I think it not particularly likely.

176. See Babcock, supra note 146, at 551 ("[N]either litigant is trying to choose 'impartial' jurors, but rather to eliminate those who are sympathetic to the other side, hopefully leaving only those biased for him."); Flowers, supra note 145, at 501-02 (expressing same).

177. See Babcock, supra note 146 , at 554 (stating that "[c] hallenges for cause . . . could not effectively screen those who share biases and prejudices common to a racial or ethnic group, or an economic or social class," because they "depend on the juror's admitting actual bias or grounds for implied bias" and some prospective jurors will not admit or be aware of such prejudices or their likely impact); George P. Fletcher, Political Correctness in Jury Selection, 29 SUFFOLK U. L. REV. 1, 5 (1995) (" $[B]$ oth sides to the trial may invoke 'peremptory challenges' to remove jurors whom they suspect of bias but as to whom they cannot convince the judge that their intuitions are correct."); Melilli, supra note 24, at 447 ("Because peremptory challenges are exercised after the challenges for cause, any prospective juror who is peremptorily struck is presumably an individual who is not subject to a valid challenge for cause.").

178. See J.E.B. v. Alabama ex rel. T.B., 511 U.S. 127, 147-48 (1994) (O’Connor, J., concurring) (maintaining that the effectiveness of peremptories in eliminating bias lies in their discretionary nature and is compromised by requiring an explanation for their exercise); Swain v. Alabama, 380 U.S. 202, 219 (1965) (indicating that the function of peremptories is to "eliminate extremes of partiality on both sides" and that this "arbitrary and capricious right ... must be exercised with full freedom, or it fails of its full purpose" (citation and internal quotation marks omitted)); see also Swift, supra note 154, at 337 ("[T] he irony of Batson is that the peremptory challenge, in its normal 'arbitrary and capricious' exercise, necessarily fails the easiest to satisfy level of equal protection review-[rational basis review] . . . and if subject to conventional equal protection analysis cannot survive." (footnote omitted)). 
the group (or groups) to which the person belongs. ${ }^{179}$ Sometimes these generalizations are accurate as to the group and sometimes they are not, ${ }^{180}$ but even in the former case, it would usually be impossible to ascertain whether they are accurate as to any individual prospective juror. ${ }^{181}$

For example, an attorney trying to establish the existence of a complex antitrust violation might strike a prospective juror with less than a high school education on the assumption that most such individuals would not sufficiently comprehend the issues. This generalization may well be accurate, but it may or may not apply to the particular person struck. Nevertheless, if the stereotype is usually true, then striking that person is more likely than not going to eliminate someone who is unfavorable to the attorney's case.

Generalizations about race and sex may likewise be true or untrue as a general matter; surely some are and some are not. ${ }^{182}$ For example, in one

179. See Flowers, supra note 145, at 498 ("Because of the scarcity of information on prospective jurors, stereotyping is an essential ingredient in exercising peremptory challenges."); Melilli, supra note 24 , at 447 (asserting that attomeys often base peremptories on group affiliations because they have limited information about individuals); see also Babcock, supra note 146, at 553 ("Common human experience, common sense, psychosociological studies, and public opinion polls tell us that it is likely that certain classes of people statistically have predispositions that would make them inappropriate jurors for particular kinds of cases.").

180. See, e.g., Babcock, supra note 146, at 553 n.28 ("[T] he Supreme Court has recognized ... that there are group biases and that these may influence the functioning of the jury."); Nancy J. King, Postconviction Review of Jury Discrimination: Measuring the Effects of Juror Race on Jury Decisions, 92 MICH. L. REV. 63, 130 (1993) (noting "the inescapable conclusions of researchers that juror race can and does affect verdicts").

181. See Babcock, supra note 10, at 1146 (stating, based on experience as a criminal defense attorney, that "[n]one of us selecting jurors in routine cases knew much about those we rejected" and that even those with resources to investigate potential jurors did not fare much better); Babcock, supra note 146, at 546-49 (describing the limitations of voir dire questioning in eliciting or identifying bias).

182. See Flowers, supra note 145, at 516-20 (providing examples of biological and social science research on differences between the sexes); Sheri Lynn Johnson, Black Innocence and the White Jury, $83 \mathrm{MICH}$. L. REv. 1611, 1625-43 (1985) (reviewing more than a dozen mock jury studies that "provide support for the hypothesis that racial bias affects the determination of guilt," including nine finding that "the race of the defendant significantly and directly affects the determination of guilt"); King, supra note 180, at 80-99 (describing, in detail and based on the available research, specific instances and ways in which juror race affects jury decisions and noting that many of these race-based realities comport with judges' suspicions about the decisionmaking behavior of specific groups); Underwood, supra note 150, at 731-32 (noting the controversial nature of "the proposition that jurors tend to favor defendants of their own race and disfavor defendants of other races" and citing contradictory studies); see also Mark Cammack, In Search of the Post-positivist Jury, 70 IND. L.J. 405, 483-84 (1995) ("[C]ultural pattems that frequently correlate with race are relevant to jury service, since those cultural factors are an important ingredient of what the jury does."); Eric L. Muller, Solving the Batson Paradox: Harmless Error, Jury Representation, and the Sixth Amendment, 106 YALE L.J. 93, 106 (1996) (suggesting that public opinion confirms social scientists' observations that "race and gender are rational, even if grossly imperfect, proxies for perspective"). Compare T. Alexander Aleinikoff, $A$ Case for Race-Consciousness, 91 CoLUM. L. REV. 1060, 1066-67 (1991) (supporting the idea that "race may have an influence on how members 
study, researchers found that white jurors were more likely to recommend the death penalty than black or Latino jurors. ${ }^{183}$ Interestingly, however, other studies suggest that black and Mexican American jurors seem to favor harsher noncapital punishments for defendants of their own race or ethnicity than do white jurors. ${ }^{184}$

Even when true, generalizations about race and sex-based behavior may not be accurate with regard to any particular member of the group. ${ }^{185} \mathrm{Nev}-$ ertheless, some do not find it quite so odious to exercise a peremptory challenge on the basis of an individual's race or sex because members of one race or sex may well be likely, as a group, to be more sympathetic or inclined toward one side in a case. ${ }^{186}$ For example, reactions to the O.J. Simp-

of society understand their worlds and each other" and casting doubt on the idea that stereotypes can be overcome with corrective information), and Fletcher, supra note 177, at 11 (describing as "reasonable" the conclusion that "a jury composed of primarily or exclusively women would show partiality to a female complainant" in a patemity case), with Flowers, supra note 145, at 510-11 (describing a case in which the government used peremptories to exclude women on the ground that female jurors might be overly sympathetic to the female defendants, yet the jury that ultimately convicted the defendants consisted mostly of women), and Marder, supra note 145, at 1080-81 \& n.157 (stating that "study after study" attest to the fact that juror race, gender, or ethnicity cannot predict how jurors will vote, except in death penalty and rape cases).

183. See King, supra note 180, at 96 (citing Frank P. Williams III \& Marilyn D. McShane, Inclinations of Prospective Jurors in Capital Cases, 74 SoC. SCI. REv. 85, 87 (1990)).

184. See id. at $97 \&$ n. 129.

185. See, e.g., id. at 107 n.169 (noting the imperfection of "[a]ssumptions about juror behavior on the basis of race... given the profound differences among persons of the same racial background and the malleable boundaries of racial identity").

186. See, e.g., Powers v. Ohio, 499 U.S. 400, 424 (1991) (Scalia, J., dissenting) (describing the "undeniable reality ... that all groups tend to have particular sympathies and hostilities-most notably, sympathies towards their own group members"); Batson v. Kentucky, 476 U.S. 79, 121 (1986) (Burger, C.J., dissenting). In his dissent in Batson, Chief Justice Burger noted that

[c]ommon human experience, common sense, psychosociological studies, and public opinion polis tell us that it is likely that certain classes of people statistically have predispositions that would make them inappropriate jurors for particular kinds of cases. ... [For example,] ... black males as a class can be biased against young alienated blacks who have not tried to join the middle class....

Id. (quoting Babcock, supra note 146, at 553) (alteration in original); see also Alschuler, supra note 10 , at 169 n.65 ("[J]ust as blacks and whites may favor Jesse Jackson for President in different ratios, blacks and whites may-if regarded collectively and statistically-approach the issues that arise in some criminal cases differently."); Cammack, supra note 182, at 478 ("[I]t seems highly likely that, at least in some types of cases, the group identity of jurors does influence juror performance."); Fletcher, supra note 177, at 16 ("We cannot achieve impartial juries by pretending there are no cultural differences that can imperceptibly spin a juror's judgment in a particular direction."). Compare King, supra note 180, at 64-72 (illustrating how the Court recently abandoned its decades-old assumption that jury discrimination affects jury decisions), with Muller, supra note 182, at 104 (noting the deepening division among the members of the Court concerning "whether group affiliation is a rational proxy for perspective"). But $c f$. Jeffrey E. Pfeifer, Comment, Reviewing the Empirical Evidence on Jury Racism: Findings of Discrimination or Discriminatory Findings?, 69 NEB. L. REV. 230, 241 (1990) (reviewing empirical research on jury racism and concluding, despite evidence of "a prejudicial ... element to jury decision-making," that "discriminatory racist behavior in jury decision-making is weaker than has been ... suggested"). 
son murder trial jury verdict were apparently so racially disparate that one commentator referred to the verdict as a "racial Rorschach test."187 Indeed, one of the arguments often raised to establish the value of diversity is that members of different races or sexes will add different perspectives on matters under consideration. ${ }^{188}$ It would be inconsistent to embrace this view with regard to diversity-based affirmative action or the importance of a diverse jury venire and reject it in the Batson context. There is no logical reason to believe that an individual's perspective will reflect his gender or ethnicity on the job, in the classroom, or even in the jury pool, but not in the jury box. ${ }^{189}$

187. Mark Whitaker, Whites v. Blacks, NewsweEk, Oct. 16, 1995, at 28, 30 (analyzing the dramatically different reactions of blacks and whites to the verdict); see also Cammack, supra note 182, at 408-09 (suggesting that the civil rights convictions of two white police officers for assaulting black suspect Rodney King seemed to corroborate suspicions that their earlier acquittal on state criminal charges stemmed from the dearth of blacks on the jury). But cf. Nat Hentoff, In Defense of the Simpson Jury, WASH. POST, Oct. 10, 1995, at A13 (reporting that, after the Simpson verdict was announced, "blacks in various settings were shown cheering the acquittal while whites, in their separate enclaves, told of their fury and disgust," but concluding that the verdict did not reflect racial differences so much as a failure of the evidence to dispel reasonable doubt).

188. See, e.g., Metro Broad., Inc. v. FCC, 497 U.S. 547, 582-83 (1990) (concluding that Congress and the Federal Communications Commission could draw a "legitimate inference" that a preference for minority owners in the award of broadcast licenses would add "varying perspectives" to the airwaves and would "be more likely to produce a 'fair cross section' of diverse content"); Richard Delgado, Storytelling for Oppositionists and Others: A Plea for Narrative, $87 \mathrm{MICH}$. L. REV. 2411,2439 (1989) (advocating exposing oneself to the views of racial minorities because "[r]acial and class-based isolation prevents the hearing of [these] diverse" voices); Richard Delgado, When a Story Is Just a Story: Does Voice Really Matter?, 76 VA. L. REV. 95, 98 (1990) (arguing that "people of color speak from a base of experience that in our society is deeply structured by racism," which leads them to have a distinctive "voice"); King, supra note 180, at 100-01 \& n.141 ("[M]any judges and scholars assume that a judge who is black, female, or a member of another 'outsider' group will bring . . . unique perspectives [to the bench] that will translate into more enlightened justice." (footnote omitted)). The Supreme Court appears to waiver in its assessment of the value and legal signifance of diversity. See, e.g., Vikram David Amar, Jury Service As Political Participation Akin to Voting, 80 CORNELL L. REV. 203, 210 (1995) (noting tensions in the Court's jurisprudence between its Sixth Amendment "flavor" approach-valuing each group's distinctive contribution to the jury process-and its recent denial of relevant differences between excluded and included groups in equal protection cases); Muller, supra note 182, at 98-105 (tracing the Court's inconsistent rulings on the "'theory of difference'-that is, the theory that jurors' race and gender are at least minimally rational predictors of their perspective" (citations omitted)).

189. See Peters v. Kiff, 407 U.S. 493, 503-04 (1972) (opining that exclusion of a large group from jury service "deprives the jury of a perspective on human events that may have unsuspected importance in any case"); Ballard v. United States, 329 U.S. 187, 193-94 (1946) (reversing a conviction where women were excluded from the jury because "the two sexes are not fungible" and "a distinct quality is lost if either sex is excluded"); Babcock, supra note 146, at 552, 553 \& n.28 (explaining that "group biases" may influence the functioning of the jury and that having a "cross section of the community" serve on the jury furthers the ideal of impartiality); Darryl K. Brown, The Role of Race in Jury Impartiality and Venue Transfers, 53 MD. L. REV. 107, 121-22 (1994) (describing "general" or "interpretive" bias on the part of jurors stemming from different life experiences and expressing itself in different race or gender-based perspectives); Cammack, supra note 182 , at 409 ("[R]ecent research on juror decision-making confirms that the identity of the decisionmaker is inseparable from, and an ingredient in, the decision."); Fletcher, supra note 177, at 13-14 
Yet the equal protection principle applied to peremptory challenges prohibits attorneys from using race or sex-based generalizations, regardless of whether they are accurate. ${ }^{190}$ As a result, even though attempting to eliminate potential jurors of a particular race or sex is unconstitutional, in some instances, it might appear to be well-intentioned. For example, a race or sexbased peremptory challenge may be undertaken to eliminate suspected bias or favoritism or to assure some other sort of fairness check rather than to perpetuate invidious stereotypes. ${ }^{191}$ And in some instances, there may even be legitimate reasons to suspect such favoritism, at least as regards the group to which the individual venireperson belongs.

The problem here stems from the inevitable tension between Batson's "antiessentialist" reasoning, which rejects "the notion that women or minori-

(recognizing that race and gender differences affect not only jury behavior, but also sympathies, loyalties, and thinking on a wide range of issues); King, supra note 180, at 75-99, 127, 130 (surveying research on the ways in which race affects jury verdicts). But see Pfeifer, supra note 186, at 244-45, 248-49 (warning that methodological limitations in studies of jury racism render findings that prejudice affects verdicts to be suspect and inconclusive).

190. See J.E.B. v. Alabama ex rel. T.B., 511 U.S. 127, $139 \mathrm{n} .11$ (1994) ("Even if a measure of truth can be found in some of the gender stereotypes used to justify gender-based peremptory challenges, that fact alone cannot support discrimination on the basis of gender in jury selection."); Underwood, supra note 150, at 733 (stating that the Court "prohibits litigants from relying on a racebased generalization to challenge jurors"); see also Fletcher, supra note 177, at 12 (indicating that the Court's Batson progeny create a "politically correct wisdom" that does not comport with lawyers' sometimes reasonable assumptions about the likely biases of certain groups). In Professor Fletcher's words:

The Justices have gotten carried away with their own passion to reform society. It might be nice for everyone to stop making generalizations about the sympathies of blacks, whites, Jews, gentiles, men, and women. Trials, however, are about convicting the guilty and preserving the freedom of the innocent. They are not about the pursuit of egalitarian ideals.

Fletcher, supra note 177, at 12.

191. See Commonwealth v. Tourscher, 682 A.2d 1275, 1277 (Pa. Super. Ct. 1996) (describing as "noble" a prosecutor's peremptory challenge of six women on a jury panel in order to secure a "fair and impartial" jury for a male defendant accused of domestic violence, even though these strikes violated the Equal Protection Clause); Alschuler, supra note 10, at 168-70 \& n.65 (implying that lawyers who exclude African Americans from juries often do so because they consider race "an empirically significant predictor" of the jurors' sentiments and that this assumption does not necessarily evidence personal racial bias, even though it is unconstitutional); Fletcher, supra note 177, at 6 (maintaining that peremptories are properly and by their nature discriminatory because, in trying to remove people they believe more likely to favor the other side, lawyers simply exclude "people who look like" the opposing party, but that such discrimination is not invidious because it does not disadvantage the jurors). Professor Fletcher argues that both sides in a criminal case should have "a fair crack at having jurors among the twelve who will lean in their direction." Fletcher, supra note 177 , at 16. He maintains that, instead of "trying to reform the way people think ... [the Justices] should open their eyes and perceive the richness of America as it really is." Id.; $c f$. Christopher L. Eisgruber, Democracy, Majoritarianism, and Racial Equality: A Response to Professor Karlan, 50 VAND. L. REV. 347, 351 (1997) (noting, in the context of electoral districting, that "[o]ne need not indulge in suspicious stereotyping in order to believe that interests will sometimes track racial lines"); King, supra note 180, at 112 ("A judicial pronouncement that the racial background of jurors in a particular case may have influenced their judgment connotes no cognitive or moral weakness on the part of those jurors."). 
ties share an 'essential' identity" common to all members of the group, and the inherently essentialist assumption underlying peremptory challenges, namely, that peremptories are a "group-based strateg[y]" that necessarily "relies on a conception of unified group identity."192 On the one hand, Batson repudiates the idea that all or even most members of the same race or sex can be presumed to share common points of view or be likely to act in common ways; thus, each juror must be judged individually, not rejected on the basis of group-based assumptions, whether or not accurate. On the other hand, peremptory challenges are the very embodiment of essentialist reasoning: They are usually exercised on the sometimes accurate assumption that a majority of the members of certain groups are likely to share a common perspective that is different from the perspective of other groups, and perhaps even to lean in a common direction on particular issues.

Thus, those who see a fundamental value in peremptories as a means of rooting out reasonably suspected group-based bias may conclude that, in the same way in which we sometimes consider certain lies to be morally justified by context, ${ }^{193}$ there will be instances in which apparently discriminatory peremptory strikes are justified as well. The fact that peremptory strikes are considered discriminatory without establishing the traditional requirement of invidiousness or animus ${ }^{194}$ adds to this perception. Consequently, some peremptory strikes might present an exception to any general moral admonition against discriminating, just as other extenuating circumstances produce exceptions to the general moral rule against lying. And if some discriminatory strikes are illegal but not immoral, perhaps they are also less deserving of the personal sanctions considered here.

If there is no moral difference between lying and discriminating, then my earlier discussion of the different mental states that could accompany such conduct applies to acts of discrimination, as well as to acts of pretextual misrepresentation. ${ }^{195}$ But if it is worse to lie than to discriminate in the context of peremptory strikes, for any of the reasons explored, then conclusions about whether personal sanctions are appropriate for various different instances of proffering a pretext would not necessarily apply to the various comparable instances of discriminating. That is, even clearly intentional discrimination-instances in which an attorney strikes a potential juror with the conscious aim to exclude him on account of his race or sex-would not necessarily warrant the same sanction as intentional pretext. Precisely because deliberate discrimination of this sort is not obviously banned by the govern-

192. Note, The Myth of Context in Politics and Law, 110 HARV. L. REV. 1292, 1293 (1997).

193. See generally BOK, supra note 169 (exploring various moral justifications for lying).

194. See notes 90 \& 191 supra and accompanying texts.

195. See text accompanying notes 141-162 supra. 
ing ethical codes in most states, ${ }^{196}$ the question of whether it ought to be sanctioned is more difficult to resolve. And again, if it is worse to lie than to discriminate, then deciding the appropriateness of a personal sanction becomes even more problematic in cases of unintentional Batson violations ${ }^{197}$ than in cases of unintentional pretext. Instances of reckless or negligent discrimination might not call for personal punishment, even if cases of reckless or negligent pretext might.

Finally, in the event that some courts do not actually search for subjective discriminatory intent in Batson-type cases and instead decide such cases without regard to the actual or likely mental state of the actor, ${ }^{198}$ the case for a personal sanction against the striking attorney becomes difficult to justify. The antidiscrimination factor discussed above-ferreting out and eradicating invidious discrimination by erring on the side of finding equal protection violations ${ }^{199}$-must be weighed against the appropriateness of personally condemning an actor who is not culpable in the traditional sense of having acted with blameworthy scienter. Some might argue that the need to eliminate this sort of discrimination is so compelling that it is comparable to the need to protect the public from things like dangerous products or adulterated food-a situation that justifies strict, personal liability. ${ }^{200}$ Others will surely disagree, arguing that the prospect of incurring personal liability on a strict liability basis will dampen even appropriately ardent advocacy.

\section{The Suitability of Sanctions}

Overall, it seems unwise to impose personal sanctions on attorneys for violating Batson by exercising discriminatory strikes. And although it may trouble some, declining to impose personal sanctions on attorneys who are found to have offered pretextual justifications may represent the wisest course of action as well, at least in most cases.

Personal sanctions, in addition to the regular remedies imposed for discriminatory strikes, should only be considered if courts are sure that they have discovered the subjective intent of the striking attorney. Without a determination that the advocate possessed a culpable mental state, it seems unjust to hold him personally responsible, especially in addition to remedying the unconstitutional violation itself.

But even if courts are making assessments of subjective intent, as the Supreme Court appears to direct them to do, ${ }^{201}$ it seems problematic to con-

196. See notes 11-14 supra and accompanying text.

197. See text accompanying notes 130-132 supra.

198. See notes 133-135 supra and accompanying text.

199. See notes $150 \& 154$ supra and accompanying text.

200. See text accompanying notes $138-140$ supra.

201. See text accompanying notes 97-124 supra. 
clude that personal sanctions are in order. Subjective intent ordinarily implies that some personal culpability is warranted, but the evidence of that intent is virtually always objective and circumstantial. Although objective, circumstantial evidence is relied on whenever courts or juries make determinations of responsibility based on subjective intent-in criminal and tort law, for example ${ }^{202}$ - the burdens of proof involved, the procedural protections afforded, and the consequences of such determinations differ. Criminal law findings of mens rea must be reached beyond a reasonable doubt. ${ }^{203}$ Tort determinations might involve monetary penalties, but would not necessarily carry the kind of personal and professional opprobrium that undoubtedly accompanies censure of the sort considered here. ${ }^{204}$ And both tort and criminal findings are accompanied by the opportunity for full-blown trials on the issue of scienter, with all the constitutional and statutory protections applicable to formal trials. Tort and criminal law scenarios differ in this respect from instances in which a court finds a Batson violation, ${ }^{205}$ and judges who already complain about the distraction Batson determinations cause to a trial certainly will not welcome formal minitrials to assess the personal culpability of

202. See, e.g., Howard v. Senkowski, 986 F.2d 24, 31 (2d Cir. 1993) (asserting that judges determine the subjective mental states of parties and witnesses "in all manner of cases" by making "inference[s] from all the pertinent circumstances").

203. See, e.g., Sandstrom v. Montana, 442 U.S. 510, 520-21 (1979) (reversing a conviction for deliberate homicide because a jury instruction may have led jurors to conclude that the state did not have to prove the necessary mens rea beyond a reasonable doubt); Karlan, supra note 70, at 117 \& n.32 (noting that, in criminal cases, mens rea must be proved beyond a reasonable doubt); Barbara D. Underwood, The Thumb on the Scales of Justice: Burdens of Persuasion in Criminal Cases, 86 YALE L.J. 1299, 1301 (1977) (same); cf. Karlan, supra note 70, at 117 (referring to the "different burdens of proof faced by criminal prosecutors and equal protection plaintiffs"). Tort determinations are usually based on a preponderance of the evidence. See Karlan, supra note 70, at 117 (noting that the preponderance burden applies in the usual civil case); Underwood, supra, at 1300$01 \&$ n.5 (noting the wide applicability of the preponderance burden in civil cases); see also PROSSER \& KEETON, supra note 138, § 38, at 239 (noting the preponderance burden for negligence). The burden of proof in tort accords with the type of determination made in the Batson context. See Karlan, supra note 70, at 117 (indicating that, in an equal protection challenge, as in civil cases generally, the plaintiff must usually prove her case by a preponderance of the evidence).

204. See Karlan, supra note 70 , at 113 (maintaining that crimes and constitutional violations, unlike torts or breaches of contract, involve "moral condemnation by the community").

205. See People v. Hameed, 666 N.E.2d 1339, 1341 (N.Y. 1996) (holding that "a full-blown evidentiary hearing," with sworn witnesses and trial-type cross-examination, is not necessary "to ensure a fair proceeding" in a Batson inquiry), cert. denied, 117 S. Ct. 704 (1997).

Presumably, in the case of ethical rules barring discrimination in jury selection, there would be an opportunity for a hearing on any disciplinary complaint made by a judge or other party against a lawyer who violated Batson. Procedural protections afforded in such proceedings might or might not compare with those applicable in a tort or criminal trial. See DEBORAH L. RHODE, PROFESSIONAL RESPONSIBILITY: ETHICS BY THE PERVASIVE METHOD 70 (1994) (stating that, because disciplinary proceedings are "quasi-criminal in nature," they embody such due process safeguards as the right to present evidence, the opportunity to cross-examine witnesses, and the privilege against self-incrimination and sometimes impose a "clear and convincing" burden of proof (internal quotation marks omitted)). 
attorneys for their Batson violations. ${ }^{206}$ In other words, the fact that we extrapolate in many contexts from largely objective, circumstantial evidence to make findings of subjective intent does not mean that a personal sanction is similarly justified in each. Surely there will be cases in which the court is mistaken about the specific mental state of the striking attorney, ${ }^{207}$ and this possibility is exacerbated by the absence of the kinds of procedural protections, such as heightened burdens of proof, that accompany more formal determinations of mental state.

Another factor that militates against personal liability, ironically, is the desire to root out discriminatory challenges. If public policy calls for vigorous efforts to eliminate discriminatory peremptory strikes, it would be appropriate for courts, in questionable cases, to err on the side of finding Batson violations. ${ }^{208}$ Where the objective evidence appears debatable and an attorney offers a plausible but weak explanation for a strike, perhaps courts ought to tip their scales toward finding an equal protection problem. However, if we want courts to rule in this way in order to wipe out all potential instances of discrimination, then, in faimess, the benefit of the doubt about personal culpability should run in the opposite direction-to the attorney exercising the strike. ${ }^{209}$

In a related vein, judges might be less inclined to find Batson violations if personal sanctions attached to errant attorneys as a result. Batson findings are made by trial judges, who often know the attorneys practicing before them. Trial judges are especially apt to know prosecutors, who appear regularly before local courts, but they are often acquainted with other attorneys as well. If trial judges understand that finding a Batson violation triggers an obligation to consider imposing personal sanctions on such attorneys, they may be disinclined to find violations, at least in close cases. And even if the

206. See J.E.B. v. Alabama ex rel. T.B., 511 U.S. 127, 147 (1994) (O'Connor, J., concurring) ("Batson minihearings are now routine in state and federal trial courts, and Batson appeals have proliferated as well. ... In further constitutionalizing jury selection procedures, the Court increases the number of cases in which jury selection-once a sideshow-will become part of the main event."). Similarly, Justice Scalia comments that, with the extension of challenges to race-based peremptory strikes to all civil jury cases,

yet another complexity is added to an increasingly Byzantine system of justice that devotes more and more of its energy to sideshows and less and less to the merits of the case.... [I]t is a certainty that the amount of judges' and lawyers' time devoted to implementing today's newly discovered Law of the Land will be enormous.

Edmonson v. Leesville Concrete Co., 500 U.S. 614, 645 (1991) (Scalia, J., dissenting). Since judges are arguably obligated to report unprofessional conduct, see note 9 supra, presumably they would be obliged to determine whether they believe a particular attorney's Batson violation involves such conduct before turning the matter over to the responsible monitoring authority for consideration.

207. See text accompanying notes $154-158$ supra.

208. See notes $150 \& 154$ supra and accompanying texts.

209. See note 159 supra and accompanying text. 
judges who make the equal protection rulings are not themselves the parties who ultimately impose the sanction-i.e., such cases might automatically be referred for professional disciplinary hearings - the awareness that personal sanctions may flow from a Batson ruling could be sufficient to cause a judge to hesitate in finding a violation. Thus, for this reason as well, if we want courts to err on the side of enforcing Batson's antidiscrimination principle, personal sanctions should not be coupled with such rulings.

When it comes to pretext, the case for personal sanctions is stronger if one believes that lying is a more serious professional breach than discriminating. Also, in the case of pretext, the question of whether the court is supposed to be, and actually is, making a determination of subjective intent raises fewer concerns. Courts ruling that a lawyer has stated a pretextual justification are more clearly making a finding about the attorney's state of mind.

Yet even findings of pretext fall short of clear rulings that the attorney has deliberately lied to the court. Judges in these cases may simply be finding that the objective, circumstantial evidence points to discrimination and hence that the nondiscriminatory justification offered for the strike must be false, but not necessarily that it was a conscious and deliberate lie. Although courts can find otherwise, cases of unconscious discrimination may lead to unconscious pretext.210 And although covering up the truth by offering a pretext implies some consciousness of the truth, the offeror may only be reckless about the accuracy of his statement. ${ }^{211}$ Thus, there should be at least some mens rea involved in most determinations of pretext, but because the specific mens rea need not be a purpose to deceive, the pretext might not be a deliberate lie.

One could argue that this nuance should not be a roadblock in the path of imposing personal responsibility for pretextual justifications. Perhaps attorneys should be sanctioned even when they make reckless or negligent misrepresentations to a court. But there is still another problem with personal liability here. If pretext is tied to discrimination in the manner discussed above, ${ }^{212}$ erring in favor of finding discrimination also means erring in favor of finding pretext. Thus, if one believes that courts should more readily find strikes unconstitutional, then one also ought to conclude that courts should err on behalf of the striking attorney when it comes to personal liability for pretexts as well as discrimination. .13 $^{21}$

Such reluctance to impose personal sanctions has disturbing conse-

210. See notes $130 \& 156-158$ supra and accompanying texts.

211. See notes 63-64 supra and accompanying text.

212. See notes 20-21 \& 30 supra and accompanying texts.

213. See note 159 supra and accompanying text. 
quences. It would mean that even when a trial judge believes that a lawyer has deliberately lied to the court, the judge should not impose liability or report the attorney for disciplinary proceedings. The courts might mitigate this seemingly harsh result by deciding that personal sanctions are generally undesirable, but appropriate in flagrant cases of intentional pretext. The same exception could also be made for extreme or obvious cases of discrimination.

It may be difficult, however, for courts to separate the egregious cases from all the others. And at least with regard to run-of-the-mill Batson findings, it will surely be difficult for courts to assess which of the many possible permutations of culpability exists. Unless courts conclude that all of the different mental states that might accompany the offer of a pretext or the exercise of a discriminatory peremptory strike warrant personal sanction, the near impossibility of figuring out which one exists in a given case weighs in favor of sanctioning none of them. If we wish to sanction only those lawyers who deliberately lie or discriminate, we must be able to identify the conscious liars and discriminators with some reasonable degree of assurance. This seems to be a difficult, if not insurmountable, task unless courts begin to conduct mini side-trials, with the full panoply of formal procedural protections, on the culpability of the striking attorney. ${ }^{214}$ For this reason, we should forego the imposition of personal sanctions on striking attorneys in most, if not all, cases and content ourselves with the presently available remedies for unconstitutional peremptory strikes.

\section{CONCLUSION}

Ethical alarms are triggered when courts find that attorneys have violated Batson by exercising peremptory strikes on the basis of race or sex and offering pretextual explanations for the strikes. Have the striking attorneys breached the applicable rules of professional conduct? Should they be personally sanctioned for lying or discriminating? Is the judge who renders the Batson ruling required to report these wayward attorneys for their ethical lapses?

The answers to such questions should depend on the personal culpability of the lawyer who exercised the strike, which, in turn, should depend on the lawyer's state of mind when he acted. As argued in Parts III and IV of this article, these violative acts may reflect a deliberate intent to lie or discrimi-

214. It might even be necessary for a judge other than the trial judge who made the Batson ruling to preside at such a trial in order to satisfy the procedural due process requirement of a neutral decisionmaker. See LAURENCE H. TRIBE, AMERICAN CONSTITUTIONAL LAW $\S \S 10-16$, at 74647 (2d ed. 1988) (noting that the Supreme Court requires hearings of an adversarial nature to be conducted "by some person other than the one initially dealing with the case" in order to facilitate complete objectivity). 
nate, an unconscious racist or sexist intent, or neither. In criminal mens rea terms, the strikes and the accompanying pretexts might have been purposeful, reckless, or negligent acts of deception or invidious discrimination. Or more rarely, they might have been entirely innocent.

Many are calling for measures that would put some teeth into Batson's antidiscrimination principle. ${ }^{215}$ Personal censure of attorneys found to have violated Batson would serve as an added deterrent to potential discriminators. However, for several reasons, imposing personal liability on the lawyers, in addition to the remedies granted for the equal protection violations themselves, represents an unwise policy choice.

First, many levels of culpability are associated with such conduct, some meriting personal sanction and others not. It will be very difficult to determine reliably which level of culpability should actually be attributed to the striking attorney in any particular case, at least without a time and resourceconsuming side-trial. For this reason, professional censure seems inappropriate, except perhaps in cases of flagrantly improper conduct.

Second, however unconstitutional discriminatory peremptories may be, there are many who maintain that strikes based on race or sex are at least understandable - and sometimes even morally warranted - as a means to secure justice for accused or litigating parties, even if these means are no longer legal because of the perceived injustice to potential jurors. The inherent conflict between Batson's antidiscrimination principle (which permits strikes only for individually demonstrable reasons) and the principle of peremptory challenges (which seeks to eliminate unprovable favoritism by allowing strikes that are attributable to group-based characteristics) creates an ethical, if not legal, dilemma. And the fact that discriminatory strikes may be found unconstitutional absent a finding of animus or invidious motivation intensifies the ethical conundrum. These considerations may make it more difficult to justify the imposition of a personal sanction against an errant attorney.

In addition, personal punishment will dampen ardent advocacy. Those who find themselves in situations that appear questionable, even when they are properly and not discriminatorily motivated, will hesitate to strike potential jurors. Personal sanctions are likely to cause an unwarranted chill.

Although many advocate more rigorous enforcement of Batson's antidiscrimination principle, beefed up enforcement would result in more findings of violations in close cases in which the striking attorney's culpability is in greater doubt. Thus, should courts apply Batson vigorously, it would be even less appropriate to sanction personally those implicated. Moreover, judges may be hesitant to find Batson violations, especially in close cases, if doing so means that attorneys they know and see regularly will be punished 
personally or professionally as a result.

On balance, it seems unwise to impose personal sanctions on attorneys who fall on the wrong side of Batson. Perhaps it is necessary to tolerate some deliberate deception and discrimination in the interest of other greater goods. 